\title{
O constitucionalismo transformador como instrumento de enfrentamento do racismo estrutural: o papel do STF ${ }^{1}$
}

\section{Transformative constitutionalism as a tool to face structural racism: the role of the Brazilian Supreme Court}

\author{
Ana Carolina Lopes Olsen ${ }^{2}$ \\ Centro Universitário Católica de Santa Catarina (Joinville, SC, Brasil) \\ ORCID: https://orcid.org/0000-0002-6646-7477 \\ E-mail: anac.olsen@gmail.com
}

Katya Kozicki ${ }^{3}$

Universidade Federal do Paraná e

Pontifícia Universidade Católica do Paraná (Curitiba, PR, Brasil)

ORCID: https://orcid.org/0000-0002-2388-0499

E-mail: katyakozicki@gmail.com

\section{Resuimo}

O racismo no Brasil tem caráter estrutural, pois impregna a raiz das relações sociais, políticas, econômicas e culturais. A partir do constitucionalismo transformador, questiona-se a postura a ser adotada pelo Supremo Tribunal Federal (STF) no seu enfrentamento, a fim de identificar e conter seus efeitos nefastos. A premissa do trabalho é normativa no sentido de defender que cabe à Corte aderir a uma leitura transformadora da Constituição na construção de decisões para enfrentar as barreiras estruturais postas na sociedade e reconhecer igual cidadania e distribuição de recursos aos grupos racializados. Mediante método hipotético-dedutivo e pesquisa bibliográfica em doutrina e jurisprudência, concluiu-se que o enfrentamento do racismo estrutural

\footnotetext{
${ }^{1}$ OLSEN, Ana Carolina Lopes; KOZICKI, Katya. O constitucionalismo transformador como instrumento de enfrentamento do racismo estrutural: o papel do STF. Suprema: revista de estudos constitucionais, Brasília, v. 1, n. 1, p. 82-118, jan./jun. 2021.

${ }^{2}$ Mestre em Direito (UFPR). Doutora em Direito (PUCPR). Pesquisadora visitante no Max Planck Institute for Comparative Public Law and International Law (2019). Professora na Escola de Direito do Centro Universitário Católica de Santa Catarina, Unidade de Joinville. Currículo Lattes: https://lattes.cnpq.br/9286504228462554.

${ }^{3}$ Mestre em Teoria e Filosofia do Direito (UFSC). Doutora em Direito, Estado e Sociedade (UFSC). Visiting research associate no Centre for the Studies of Democracy, University of Westminster (Londres, 1998-1999). Estágio pós-doutoral (teoria do direito e teoria constitucional) na Benjamin N. Cardozo School of Law/NY (2012-2013). Professora titular de Teoria do Direito da UFPR e da PUCPR. Programas de graduação e pós-graduação em Direito. Pesquisadora do CCONS - Centro de Estudos da Constituição Pesquisadora do CNPq (bolsista de produtividade em pesquisa). Currículo Lattes: https://lattes.cnpq.br/8804746815321094.
} 
exige do STF atuação antirracista no sentido de promover e facilitar transformações do quadro social, em diálogo com a sociedade civil e instituições, mediante um compromisso material, sincero e efetivo com a inclusão social.

\section{Palavras-chave}

Racismo estrutural; Constitucionalismo transformador; Supremo Tribunal Federal; Antirracismo; Inclusão social.

\section{Suimário}

1. Introdução. 2. Racismo estrutural e direito antirracista. 3. A potencialidade da corte constitucional no constitucionalismo transformador. 4. Constitucionalismo transformador para um STF antirracista. 5. Conclusão.

\section{Abstract}

Racism in Brazil has a structural character for it penetrates the foundations of social, political, economic, and cultural relations. Based on the transformative constitutionalism theory, this study investigates the role to be performed by the Brazilian Supreme Court to confront structural racism, identifying and blocking its harmful effects. From a normative premise, this research states that the Court should adhere to a transformative reading of the constitution to strengthen its adjudication so that its decisions may face the structural barriers built by the society which prevent the recognition of equal citizenship and distribution of resources to racialized groups. Employing hypothetical-deductive method and bibliographic research on jurisprudence and legal decisions, this study has concluded that the confrontation of structural racism requires from the Supreme Court an anti-racist course of action to promote and facilitate social change, for which dialogue with civil society and public institutions is a requirement as well as a sincere and effective commitment to social inclusion.

\section{Keywords}

Structural Racism; transformative constitutionalism; Federal Supreme Court; Antiracism; Social Inclusion. 


\section{Contents}

1. Introduction. 2. Structural racism and anti-racist law. 3. The potential of the constitutional court in transformative constitutionalism. 4. Transformative constitutionalism for an anti-racist Supreme Federal Court. 5. Conclusion.

\section{[...] são ações que diminuem as desigualdades. ${ }^{4}$}

\section{Introdução}

A sociedade brasileira é majoritariamente negra ou parda, como apontam os dados do IBGE (SISTEMA IBGE DE REPERCUSSÃO AUTOMÁTICA, 2020). Seria, portanto, de se esperar que essa maioria estivesse visível e equitativamente distribuída em todas as camadas sociais, ocupando espaços no alto escalão das empresas, na representação política, na academia, só para tomar alguns exemplos. E não são necessárias estatísticas para se constatar uma ausência brutal. Onde estão os negros brasileiros? Nas comunidades periféricas, no cárcere, no subemprego, nas ruas. Esta realidade normalizada, mas de flagrante inequidade, é a marca mais gritante do racismo brasileiro. Um racismo que independe de uma discriminação voluntária e consciente, dirigida a um grupo inferiorizado em virtude de sua raça - aqui compreendida como uma categoria histórica e social a justificar a dominação de um grupo sobre outro. $\mathrm{O}$ racismo que está em um ponto anterior e fundador daquele que se materializa nas instituições. Esse é a premissa a partir da qual se desenvolve o presente estudo: o racismo está na estrutura da sociedade brasileira.

Essa realidade tem sido levada ao conhecimento do Supremo Tribunal Federal nos últimos anos. Ele foi provocado a se manifestar sobre cotas raciais, impulsionamento financeiro de campanhas políticas de candidatas e candidatos negros, o descarte de vidas negras no sistema prisional, nas operações policiais, nos quilombos. A Constituição de 1988 tem sido invocada em seu caráter mais emancipatório e transformador para comandar medidas que sirvam concretamente a gerar soluções para esse quadro. Nesse diapasão, o STF tem sido convocado a adotar medidas antirracistas.

Pensar o viés transformador da Constituição implica nela reconhecer um projeto de longo prazo que busque enfrentar as barreiras estruturais da sociedade a fim de realizar um projeto de inclusão e igualdade substancial. Essa é a tônica do 
constitucionalismo transformador, movimento cujo alcance e balizas vêm sendo discutidos na doutrina e nos tribunais. Trata-se de uma concepção potencializadora da normatividade constitucional teorizada a partir de Constituições que marcam a transição de sociedades autoritárias e excludentes para democracias sociais. Essa leitura se aplica a maior parte das Constituições latino-americanas, dentre as quais a brasileira.

Uma das características do constitucionalismo transformador é a centralidade atribuída às cortes constitucionais. Em sociedades em que a corte constitucional consegue preservar sua independência diante dos demais poderes para praticar a judicial review e mesmo para controlar políticas públicas, os juízes constitucionais podem funcionar como árbitros que colocam em diálogo e interação os poderes públicos e os movimentos sociais a fim de que soluções condizentes com a inclusão e a promoção da igualdade sejam atingidas. Mais além, o constitucionalismo transformador apregoa a aproximação dialógica das cortes domésticas com as cortes internacionais, a fim de implementar os compromissos internacionais dirigidos a inclusão que são partilhados pelos projetos constitucionais.

Partindo, portanto, da premissa de que a Constituição de 1988 permite ser interpretada e aplicada segundo uma perspectiva transformadora, que o enfrentamento do racismo estrutural demanda mudanças mais profundas na sociedade, e que essas mudanças têm sido demandadas perante a Corte constitucional brasileira, esse estudo debruçou-se sobre o seguinte problema de pesquisa: como deve atuar o Supremo Tribunal Federal no enfrentamento do racismo estrutural na sociedade brasileira a partir do marco teórico do constitucionalismo transformador?

A partir de uma pesquisa conduzida pelo método hipotético-dedutivo, em que se empregou pesquisa bibliográfica em doutrina e jurisprudência, pretende-se defender a adesão do STF ao constitucionalismo transformador a fim de enfrentar, em sentido radical, o racismo estrutural presente na sociedade brasileira. Essa postura legitimará e fortalecerá a adoção de medidas judiciais voltadas para o enfrentamento das barreiras estruturais do quadro social que tem no racismo uma de suas estruturas fundantes. Não deve, contudo, isolar-se dos demais poderes nem da sociedade civil, pois a conjunção dialógica de esforços servirá para garantir às decisões legitimidade, bem como efetividade.

Ressalte-se que esse estudo se centra no espaço de atuação da corte constitucional e, como afirmado, segue uma premissa normativa, no sentido de utilizar o substrato teórico e jurisprudencial pesquisado para defender uma postura a ser adotada pelo STF a fim de enfrentar o racismo estrutural, em atendimento às condições de 
legitimidade alinhavadas pelo constitucionalismo transformador. O efetivo impacto social de suas decisões foge ao âmbito da presente análise, que se centra na construção de uma jurisdição antirracista capaz de contribuir para o enfrentamento do racismo estrutural, minimizando suas consequências nocivas.

Para tanto, o texto foi dividido em três partes.

$\mathrm{Na}$ primeira, buscou-se apresentar a categoria do racismo estrutural como elemento que marca as relações sociais, econômicas, políticas e culturais brasileiras, desmistificando-se a ideia falaciosa de democracia racial. A partir da compreensão do alcance do racismo nesta dimensão, apresentou-se o direito como um elemento institucional capaz de promover medidas de combate aos efeitos mais graves do racismo. Ainda que não consiga sozinho mudar a realidade, o Direito - e sobretudo as normas constitucionais - tem se mostrado como uma ferramenta de mudanças sociais - impulsionando novos comportamentos, remodelando as instituições e incorporando a pauta do racismo às relações sociais.

$\mathrm{Na}$ segunda parte, o estudo definiu e caracterizou o constitucionalismo transformador, discutindo suas premissas e suas potencialidades. Buscou-se enfatizar que o risco inerente à centralidade que ele atribuiu às cortes constitucionais deve ser sopesado com a capacidade destas em alavancar mudanças enfrentando barreiras de ordem política, o que pode ser especialmente produtivo no tratamento do racismo estrutural.

Finalmente, na terceira parte foi feito um estudo do tratamento dispensado pelo STF ao racismo, remontando às discussões do racismo como tipo penal e à constitucionalidade das ações afirmativas para demonstrar que, nos últimos anos, o racismo estrutural tem embasado litígios estruturais: Arguições de Descumprimento de Preceito Fundamental (ADPF) 347, 635 e 742. A pesquisa empírica adotada nesse tópico foi realizada no mês de fevereiro de 2021, no ambiente de busca virtual de jurisprudência do sítio do STF na internet (www.stf.jus.br), tendo por parâmetro a busca pelos verbetes "raça” e "racismo", e considerados apenas os julgados posteriores à promulgação da Constituição em $1988^{5}$. Importa destacar que o objetivo do presente

\footnotetext{
${ }^{5}$ A pesquisa centralizou-se nos acórdãos, desconsiderando decisões monocráticas, por buscar compreender uma posição mais institucional do órgão, ainda que os votos individuais tenham sido analisados. Das duas repercussões gerais encontradas, uma tratava de discriminação em virtude de tatuagens (RE 898.450) e outra sobre prescrição (RE 852.475). Do universo de 53 acórdãos encontrados, foram desprezados 9 acórdãos que empregaram a palavra "raça" para fazer referência a raça de animais (ADI 3.776, ADI 2.514, RMS 21.524, AI 552.178 AgR, RE 77.661, RMS 3.396, ADI 1.856, HC 97.051, AI 291.332), 12 acórdãos que tratavam de processos relacionados a extradição ou estrangeiros (Ext. 1.362, 1.598, 1.104, 1.613, 1.603, 9.947, 1.288, 1.327, 1.405, HC 119.717, HC 117.878, RE 161.243), por não abordarem diretamente o tema do racismo, 12 acórdãos que trataram de outros tipos de discriminação não fundada na raça (Inq 3.590, MI 4.733, ADO 26, ADI 5.357, ADI 2.341, ADI 5.543, ADI 5.617, ADPF 130, ADPF 526, ADPF 460, ADPF 457, RE 898.450), o acórdão ADI 3.166 que tratava de competência legislativa, o acórdão RE 852.475
} 
artigo é propor o constitucionalismo transformador como uma ferramenta a ser empregada pelo STF no enfrentamento do racismo estrutural, de modo que o estudo jurisprudencial se destinou a demonstrar tão somente a evolução de abordagem do tema na Corte, superando a análise do racismo individual de caráter comportamental para, nos últimos anos, enfrentar o tema pela via dos litígios estruturais, em abordagem mais atenta ao racismo como elemento estrutural da sociedade brasileira. É nessa última dimensão que o potencial transformador é mais frutífero, cabendo à Corte dar efetividade ao projeto constitucional de inclusão social e igualdade material.

\section{Racismo estrutural e direito antirracista}

O histórico da escravidão no Brasil vai além de representar um passado inglório de sofrimento e morte. O modo de produção econômico que forjou as relações sociais do Brasil Colônia impregnou com racismo a estrutura da própria sociedade brasileira.

Luciano Góes (2018, p. 40-41) defende que o racismo teria raízes antigas, retomando há cerca de 1.500 a.C., com fundamento no livro sagrado do Hinduísimo (Rig-Veda). O líder dos invasores arianos (tribos autodenominadas arri ou ária, de pele clara) teria determinado o extermínio de seus oponentes dasyu (nome coletivo para negros) a fim de “[...] eliminar a pele negra da face da Terra” (GÓES, 2018, p. 40). Aristóteles, em seu tratado Fisionogmica, elaborou referências deterministas e depreciativas aos povos negros. Entretanto, foi no século 16 que as categorias essenciais ao racismo foram definitivamente forjadas, como a associação do negro aos animais com o termo "mulato", filhote da mula. Para Sílvio Almeida (2020, p. 2527), a concepção de raça aplicada aos seres humanos foi construída artificialmente no iluminismo do século 16 e fundamentou a distinção entre o homem civilizado e o selvagem, fornecendo as bases do projeto colonialista do século 18 no sentido de levar o modo de vida "civilizado" aos "povos primitivos".

O processo de colonização - assim como o de escravização - implicou atos de soberania enquanto poder de definir a vida e a morte das pessoas. Como ensina Mbembe (2018, p. 41) “[...] a soberania é a capacidade de definir quem importa e quem não importa, quem é 'descartável’ e quem não é”. O sistema escravagista brasileiro durou 370 anos, o mais duradouro do mundo, e foi o responsável por desencadear um processo genocida que marcou a formação da sociedade brasileira até os dias atuais. A descartabilidade da vida negra foi um marco dos anos de escravidão, manteve- 
se na transição para uma economia de trabalho assalariado, e segue corriqueira. $\mathrm{O}$ abolicionismo do século 19 lançou à Guerra do Paraguai milhares de negros com a promessa da liberdade. Os poucos que voltaram com vida enfrentaram a transição do regime escravista para uma república excludente(GÓES, 2018, p. 43-44). Essa república sempre tratou com menosprezo os egressos da escravidão e seus descendentes de modo que o racismo está na própria formação da sociedade brasileira.

Raça, importante frisar, não é um dado biológico, mas relacional e histórico concebido pela forma de tratamento destinado a certos grupos sociais por aqueles que detêm o poder político e econômico (ALMEIDA, 2020, p. 24). A raça serve para diferenciar entre "nós" e "eles". Na medida em que o colonialismo brasileiro estava fundado no modo de produção com mão de obra escravizada, a inferiorização e desumanização do grupo de pessoas negras se tornaram elemento essencial da sociedade contemporânea. Essa classificação permite conhecer o passado e compreender o presente (MUNANGA, 2010, p. 193).

O racismo, no Brasil, se desenvolveu sistematicamente como um ingrediente das relações sociais, políticas, jurídicas, culturais. Diferentemente de outros Estados que adotaram um racismo declarado, como os Estados Unidos com as Leis Jim Crow, ou a África do Sul com o radicalismo do apartheid, o Estado brasileiro foi gestado por ele e o perpetuou a partir de ideologias falaciosas como a da democracia racial. O mito segundo o qual o povo seria naturalmente miscigenado escondeu e ainda esconde no ideário de grande parte da população a realidade discriminatória. Diferentemente da vivência de negros em regimes abertamente racistas, negros no Brasil procuram se identificar como "mestiços", "pardos", para passar por um processo de assimilação branqueadora e, com isso, distanciar-se das práticas que inferiorizam sua negritude. $\mathrm{O}$ mito da democracia racial prejudicou o avanço de movimentos voltados para o reconhecimento do valor da cultura negra - como o Black Power nos Estados Unidos - e possibilitou que mesmo os negros perpetuassem o racismo (GÓES, 2018, p. 50). Por isso a grande maioria dos brasileiros tem dificuldade em compreender que involuntariamente realizam práticas racistas, o que permite sugerir a existência de um "racismo à brasileira", dissimulado e, por isso mesmo, mais perverso (MUNANGA, 2010, p. 170).

Assim compreendido, o racismo vai além de outras manifestações humanas como o preconceito e a discriminação. Não é apenas um juízo de valor depreciativo dirigido a um grupo social estereotipado, racializado (preconceito), ou efetiva manifestação de poder pela qual se atribui voluntariamente tratamento diferenciado a esse grupo (discriminação direta) ou ignora-se que normas jurídicas, políticas públicas 
e oportunidades sociais o atingem de forma diferenciada (discriminação indireta) (ALMEIDA, 2020, p. 30-31).

O racismo tem como marco distintivo seu caráter sistêmico: “é uma forma sistemática de discriminação que tem a raça como fundamento, e que se manifesta por meio de práticas conscientes ou inconscientes que culminam em desvantagens ou privilégios para indivíduos, a depender do grupo social a que pertençam” (ALMEIDA, 2020, p. 32). A partir dessa compreensão, vislumbra-se que mesmo as pessoas não preconceituosas podem praticar atos racistas, o que permite tratar do tema na perspectiva de sua capilaridade radical, é dizer, como raiz que fundamenta as relações sociais.

Compreendido como forma sistêmica de discriminação, o racismo pode se revelar em manifestações parciais, quais sejam, o racismo individualista e o racismo institucional. Mas o racismo em si, como defende Sílvio Almeida (2020), está na estrutura das relações sociais.

A concepção individualista do racismo está associada a uma manifestação subjetiva de uma pessoa ou grupo: a pessoa é racista porque adotou uma conduta discriminatória dirigida ao grupo em virtude de sua raça. Ele tem caráter comportamental. Nesse viés, o cidadão racista pratica atos condenados pela moral e também pelo direito. Aqui se compreende o racismo como "crime inafiançável e imprescritível”, segundo o inciso XLII do artigo $5^{\circ}$ da Constituição Federal. Significa que o direito procurou responder ao racismo individualista com a previsão de um crime, punível com reclusão, como especifica a Lei no 7.716, de 1989.

A discriminação racial, contudo, não se encontra apenas na prática de indivíduos ou grupos racistas, mas decorre de práticas institucionais. Nesse diapasão se passa a compreender o racismo institucional como manifestação decorrente do próprio funcionamento das instituições, que carregam em si os conflitos presentes na sociedade. A discriminação racial contamina a criação das normas jurídicas, as relações de representação política, as práticas de segurança pública, podendo se manifestar de forma direta - como se verificou nas leis de segregação racial nos Estados Unidos ou no regime do apartheid na África do Sul - ou indireta, não imediatamente aferível. Nesse último caso, o racismo pode se encontrar mascarado sob a ideia de uma igualdade formal, dissimulado nas brechas, nos vazios normativos da regulação social. Uma manifestação patente do racismo institucional no Brasil pode ser identificada no enfrentamento policial da criminalidade. Segundo o Anuário Brasileiro de Segurança Pública (2020, p. 18), pessoas negras representam 79,1\% das vítimas letais de intervenções policiais. Significa que o sistema de segurança pública 
reconhece no negro o criminoso potencial, e o direito penal, concebido a partir de critérios supostamente objetivos de antijuridicidade, não evidencia a sua seletividade.

Concebido na modalidade institucional, o racismo pode ser enfrentado pela mudança em como se manifestam os poderes institucionais - o Estado, a escola, a religião (ALMEIDA, 2020, p. 38-41). Nesse âmbito, o direito tem um importante papel a cumprir, já que uma intensa militância em favor do reconhecimento legal e judicial da cidadania pode ensejar mudanças significativas, como o caso da Lei $\mathrm{n}^{\circ} 12.990$, de 2014, instituidora da política de cotas para concursos públicos (ALMEIDA, 2020, p. 148).

O racismo, contudo, está entranhado de forma ainda mais profunda. É preciso reconhecer que o racismo institucional que se materializa pela imposição de regras e padrões racistas reflete uma dada ordem social. É nessa sociedade em que se realizam os conflitos raciais, que o preconceito introjetado por mecanismos educativos contamina a racionalidade a ponto de tornar-se inconsciente e até mesmo involuntário. Do preconceito germina a discriminação agora também normalizada (MUNANGA, 2010, p. 177), de modo que relações políticas, econômicas e jurídicas excluem ou mantêm excluídos grupos racialmente definidos, passando muitas vezes a salvo de reflexão crítica. O fato de a sociedade brasileira, com cerca de $54,9 \%$ da população parda e negra, ser representada por um Congresso Nacional essencialmente branco $(79,9 \%$ dos senadores e $75 \%$ dos deputados federais) evidencia um racismo normalizado (BRASKEM, 2019). Assim, "[...] as instituições são apenas a materialização de uma estrutura social ou de um modo de socialização que tem o racismo como um de seus componentes orgânicos. [...] as instituições são racistas porque a sociedade é racista" (ALMEIDA, 2020, p. 47). O racismo é estrutural porque está na estrutura da sociedade.

A sociedade brasileira que emergiu do colonialismo trouxe, no bojo de suas relações econômicas e sociais, o privilégio dos grupos brancos em detrimento dos negros e pardos. Um privilégio informado tanto por uma dimensão ideológica investida em um ideal de branquitude, como também pela omissão do Estado em adotar qualquer medida inclusiva da população outrora escravizada. Para além do extermínio físico causado pela escravidão, africanos e seus descendentes tiveram por séculos sua identidade anulada, foram descartados como inúteis pelo sistema econômico em processo de modernização e excluídos da cidadania (BERSANI, 2018, p. 191-192; GÓES, 2018, p. 44).

Essa discriminação sistêmica herdada da escravidão perdura no Brasil mesmo depois de uma Constituição Federal com pretensão marcadamente igualitária, ainda que leis inclusivas tenham sido recentemente promulgadas. E isso porque o racismo 
não está na epiderme do corpo populacional brasileiro, e sim em seus músculos e ossos. Nesse sentido:

O racismo estrutural corresponde a um sistema de opressão cuja ação transcende a mera formatação das instituições, eis que perpassa desde a apreensão estética até todo e qualquer espaço nos âmbitos público e privado, haja vista ser estruturante das relações sociais e, portanto, estar na configuração da sociedade, sendo por ela naturalizado. Por corresponder a uma estrutura, é fundamental destacar que o racismo não está apenas no plano da consciência - a estrutura é intrínseca ao inconsciente. Ele transcende o âmbito institucional, pois está na essência da sociedade e, assim, é apropriado para manter, reproduzir e recriar desigualdades e privilégios, revelando-se como mecanismo colocado para perpetuar o atual estado das coisas (BERSANI, 2018, p. 193).

Essa análise, contudo, não deve levar ao fatalismo ou à inação. Todo o contrário. Compreender o racismo na sua concepção estrutural significa enfrentá-lo pela raiz. Ainda que o Direito não seja capaz de exterminá-lo, pois o racismo está na estrutura da sociedade que o produz (ALMEIDA, 2020, p. 51), é inegável que o Direito tem um papel a cumprir. Luiz Gama foi talvez um dos primeiros artífices do movimento negro ao usar as normas jurídicas em seu favor: ainda que o Direito não seja a solução, ele é uma ferramenta na luta pela liberdade (ALMEIDA, 2020, p. 148).

Mesmo quando dirigido ao combate ao racismo individualista, como se verifica nas normas jurídicas que criminalizam as práticas discriminatórias do racismo e as ofensas fundadas no preconceito racial, ele tem um efeito pedagógico moralizante que enfraquece a ideologia racista. Quando institui ações afirmativas, combate os efeitos nefastos do racismo institucional e alavanca a inclusão social. Significa que o Direito é capaz de atacar dois pontos essenciais que mantêm ativo o racismo estrutural: o direito de ser reconhecido como cidadão participante da vida em sociedade em igualdade com todos os demais, e o direito às mesmas oportunidades na distribuição de bens. Essas duas modalidades de injustiça coexistem e precisam ser enfrentadas de forma complementar (FRASER, 1995, p. 141-142).

Assim, cabe ao Direito enfrentar o racismo promovendo tanto o reconhecimento (valorização) dos grupos racializados como a distribuição de bens e oportunidades. Nesse sentido, quando se pensa no combate ao racismo estrutural pela afirmação de uma igualdade substancial, é necessário que o Direito foque claramente nas desvantagens vivenciadas pelos grupos racializados, combatendo, criminalizando, responsabilizando o preconceito, o estereótipo, a humilhação e toda forma de violência a eles dirigida. Mais além, deve garantir voz e participação efetiva a esses grupos a fim 
de conter a exclusão social e política de que são vítimas. E mais além, cabe ao Direito acomodar as diferenças e promover mudanças estruturais (FREDMAN, 2016, p. 727).

O Direito tem essa potencialidade: é "a forma mais eficiente de combate ao racismo" (ALMEIDA, 2020, p. 140), ainda que seja um produto de uma sociedade que o traz em seu âmago. Na medida em que essa sociedade abriga movimentos sociais contra-hegemônicos, que denunciam o racismo e cobram medidas concretas contra ele (movimentos antirracistas), também o Direito passa a normatizar soluções para essas tensões sociais (WESTRUPP; LIMA, 2020, p. 79-80). A partir dessa compreensão, o Direito e seus intérpretes devem ser moldados para enfrentar o racismo no lugar de instrumentalizá-lo. Se o combate ao racismo estrutural só se faz pela adoção de práticas antirracistas, o Direito deve ser também antirracista (ALMEIDA, 2020, p. 48, 150-151).

A Constituição brasileira de 1988 assumiu esse compromisso quando apontou, em seu preâmbulo, o ideal de “[...] igualdade e a justiça como valores supremos de uma sociedade fraterna, pluralista e sem preconceitos”. Mais além, apontou como objetivo fundamental da República “[...] construir uma sociedade livre, justa e solidária; erradicar a pobreza e a marginalização e reduzir as desigualdades sociais e regionais; promover o bem de todos, sem preconceitos de origem, raça, sexo, cor, idade e quaisquer outras formas de discriminação”. Ainda, repudiou o racismo como princípio das relações internacionais, e garantiu como direito fundamental o combate ao racismo individualista, criminalizando-o em caráter “[...] inafiançável e imprescritível, sujeito à pena de reclusão, nos termos da lei”. Buscando transformar uma realidade social impregnada pelo racismo, a Constituição serviu de norte para outras legislações, como a Lei no 10.639 , de 2003, que determinou o ensino de história da África nas escolas como cultura afro-brasileira.

Contudo, para que a Constituição compreendida em uma vertente transformadora efetivamente logre modificar as bases da sociedade racista, é necessária a atuação de uma jurisdição comprometida com essa transformação. Uma jurisdição antirracista. É nesse panorama que entra em cena o constitucionalismo transformador.

\section{A potencialidade da corte constitucional no constitucionalismo transformador}

Se o combate ao racismo estrutural exige práticas antirracistas, há que se pensar em mecanismos que enfrentem o problema para além de seus deletérios efeitos e desencadeiem mudanças na estrutura da sociedade racista. Para que o 
Direito logre vencer esse desafio, ele precisa potencializar seu caráter normativo. $\mathrm{O}$ constitucionalismo transformador é um movimento que pode traduzir essa guinada a partir de uma compreensão da Constituição como norma compromissada com o combate à exclusão social e promoção da igualdade substancial.

A partir do famoso paper de Karl E. Klare (1998) pensado para a transição da sociedade sul-africana do regime excludente e autoritário do apartheid para uma democracia igualitária, o constitucionalismo transformador revela um aporte teórico com perspectivas ainda em evolução, porém com características bastante claras: (i) o foco na potencialidade transformadora do Direito, (ii) especialmente calcada em uma atuação jurisdicional comprometida com os ideais constitucionais e, nessa linha, (iii) com a efetiva transformação das estruturas geradoras de desigualdade e violência. Os comandos constitucionais passam a ser interpretados para a realização dos fins políticos estabelecidos na Constituição.

O constitucionalismo transformador corresponde, segundo Klare (1998, p. 150), a um projeto de implementação constitucional de longa duração dirigido à mudança das estruturas sociais e políticas para a promoção de igualdade, respeito aos direitos humanos fundamentais e democracia participativa. Ele não abre mão das ferramentas institucionais do Estado de Direito e está materialmente comprometido com a promoção de inclusão - precisamente para alavancar a transformação/superação das barreiras que outrora construíram uma sociedade excludente. ${ }^{6}$ Todavia, a fórmula mais tradicional da separação dos poderes própria das Constituições liberais precisaria de uma nova leitura - mais ativista (e para Klare mais politizada) da jurisdição constitucional (KLARE, 1998). Esse constitucionalismo traz em si uma leitura prospectiva dos comandos constitucionais, determinando que o desenho constitucional (os direitos e garantias processuais, a estruturação e definição das competências dos poderes estatais) esteja pautado pela realização de um ideal transformador.

Essa compreensão permite verificar que a Constituição brasileira de 1988 desenhou um projeto de sociedade muito apartado daquela que vivenciou a ditadura civil-militar. Mais além, percebendo as principais mazelas que afligem a realidade nacional há séculos, o processo constituinte informado por uma intensa confluência de desejos, aspirações e denúncias plantou uma promessa política audaciosa com um extenso rol de garantia de direitos e compromissos político-estatais. As normas

\footnotetext{
${ }^{6}$ Isso não significa que o constitucionalismo transformador apenas se verifique em Constituições do Sul Global, notadamente África e América Latina. Fowkes (2015, p.1) observa que, em Estados cujas Constituições se apresentem como fórmula para uma sociedade melhor, indicando medidas nesse sentido, também seria possível identificar o constitucionalismo transformador.
} 
constitucionais assumiram o papel de chave a ressignificar a atuação dos agentes públicos, e mesmo da sociedade civil em geral.

A dívida do Brasil para com o povo negro permeou o processo constituinte de 1986-1987, como se depreende dos trabalhos da Subcomissão dos Negros, Populações Indígenas, Pessoas Deficientes e Minorias (SANTOS, 2015, p. 64). ${ }^{7}$ A pretensão dos representantes do movimento negro, traduzida nas palavras da então deputada federal Benedita da Silva, era chamar a atenção para "uma maioria que ficou até então marginalizada", de modo a promover "o resgate da dívida social" (SANTOS, 2015, p. 66). A dificuldade para trazer o tema do racismo para o ambiente político já era manifesta, mas a intenção de promover uma transformação efetiva foi patente:

Não quero que esse tema seja discutido em cima, pura e simplesmente, do emocional, do favor, da caridade, desse sentimento que, às vezes, envolve nessas questões. [...] Estamos tratando de uma questão política nesse exato momento, dando condição de que a lei possa abrigar, a Constituição possa abrigar dentro da lei toda essa coisa que estamos há séculos, aí, batalhando para que seja reconhecida, para que seja direito, para que a gente possa exercer plenamente a nossa cidadania (Benedita da Silva apud SANTOS, 2015, p. 69, grifo nosso).

O direito constitucional brasileiro passava, pela primeira vez, por um processo de conscientização que ensinava sobre o passado de violência e estigmatização dirigido ao povo negro. Ainda que a Constituição fosse fruto de uma sociedade estruturalmente racista, era resultado de um compromisso político dessa mesma sociedade que refletia sobre si mesma e estava disposta a enfrentar suas chagas. ${ }^{8}$ Embora a redação final da Constituição tenha perdido o foco mais detalhado e específico de combate ao racismo (resultado das inúmeras versões decorrentes do processo político de sistematização), avançou significativamente em relação às Constituições passadas com a menção deliberada ao racismo e sua criminalização, bem como a repressão a toda e qualquer forma de discriminação (SANTOS, 2015, p. 178-179).

\footnotetext{
${ }^{7}$ Embora tenha sido desvalorizada em relação às demais Subcomissões, trabalhando frequentemente com baixo quórum e pouca visibilidade na mídia (SANTOS, 2015, p. 174), o resultado de seus trabalhos foi determinante no processo de incorporação de pautas transformadoras pela Constituição Federal de 1988.

${ }^{8}$ Em sentido contrário, Flauzina e Pires (2020, p. 1214) afirmam que a Constituição manteve um modelo de convivência social calcado na igualdade formal e na chancela do genocídio negro. Essa perspectiva contribui para reconhecer que o racismo estrutural permanece formando a sociedade brasileira. Todavia, entende-se que a Constituição não chancelou normativamente o racismo nos seus silêncios, mas procurou enfrentá-lo no pouco que afirmou. As normas constitucionais vigentes permitem uma interpretação emancipatória e é nesse sentido que se realiza o presente estudo.
} 
Pensar a Constituição Federal de 1988 a partir de uma leitura transformadora, ainda que se reconheça que ela não é transformadora em todos os seus aspectos ${ }^{9}$ nem tão transformadora quanto poderia ser, permite potencializar as conquistas e os avanços no combate ao racismo estrutural, cobrando de seus intérpretes um compromisso jurídico, moral e político com essa pauta.

Nesse diapasão, o movimento do constitucionalismo transformador confere à corte constitucional um papel relevante, muitas vezes protagonizando ações que levam à revisão das estruturas que comprometem a realização dos ideais constitucionais. Essa centralidade atribuída às cortes constitucionais com inspiração no modelo sul-africano (KLARE, 1998) implica a responsabilidade pela construção de decisões judiciais dotadas de justificação racional, fundamento nos textos e precedentes legais, mas também nos valores morais fundadores da nova ordem constitucional. ${ }^{10}$

Oconstitucionalismo transformador projeta, portanto, uma boa dose de ativismo judicial no sentido de que a interpretação das normas constitucionais fundamente a realização de valores inclusivos. Essa pauta seria refratária a qualquer proposta de um constitucionalismo transformador guinado para tendências conservadoras notadamente diante de Constituições comprometidas com a igualdade substancial, em contextos sociais como os latino-americanos, marcados por exclusão e violência. Assim, se provocada a realizar uma leitura conservadora das normas constitucionais a fim de invalidar legislações progressistas, cabe à corte constitucional promover interpretação constitucional no sentido da inclusão, validando leis e políticas públicas comprometidas com o ideal transformador da Constituição. Assim agiu o STF no julgamento da ADPF $186,{ }^{11}$ em que foi provocado a declarar inconstitucional a política de cotas raciais adotada pela Universidade de Brasília, mas reconheceu sua constitucionalidade a partir do projeto igualitário e inclusivo da Constituição Federal. Entretanto, essa leitura inclusiva deixou de ser realizada no julgamento da ADI $3.092,{ }^{12} \mathrm{em}$ que a Corte teve oportunidade de validar legislação estadual que limitava a participação de empresas em processos de licitação se, em seus quadros, houvesse pessoas condenadas pela prática de racismo, entre outras discriminações.

\footnotetext{
${ }^{9}$ Contudo, permanece válida e aplicável ao caso brasileiro a proposta de Roberto Gargarella (2014) defendida em "La sala de máquinas de la Constitutición”. As Constituições latino-americanas que incorporaram extenso rol de direitos, a fim de acomodar as pretensões dos movimentos sociais por maior igualdade, inclusão social, econômica e política, não lograram superar plenamente a estrutura institucional de concentração de poder na figura do Executivo presidencialista.

${ }^{10}$ Existe uma divergência doutrinária entre Klare (1998, p. 161) e Roux (2009, p. 267-269), na medida em que o primeiro defende um método "pós-liberal" de interpretação e aplicação da Constituição, declaradamente político, e o segundo sugere o emprego da teoria da única decisão correta elaborada por Ronald Dworkin. A proposta de Roux torna mais palatáveis os audaciosos aspectos do constitucionalismo transformador em ambientes jurídicos como o brasileiro.
}

${ }^{11}$ STF, ADPF 186, Tribunal Pleno, Rel. Min. Ricardo Lewandowski, j. 26 abr. 2012.

${ }^{12}$ STF, ADI 3.092, Tribunal Pleno, Rel. Min. Marco Aurélio, j. 22 jun. 2020. 
Como pondera Fowkes (2015, p. 17), a corte constitucional não deve boicotar a Constituição, mas promover, com compromisso e responsabilidade, uma leitura transformadora a fim de afastar os entraves que impedem a realização do projeto constitucional inclusivo. $\mathrm{O}$ constitucionalismo transformador não é um conceito vazio a endossar toda e qualquer transformação. Ele tem um viés material concreto elaborado em atenção aos processos de transição de autocracias para democracias: promoção e garantia dos direitos humanos, combate à exclusão e promoção da igualdade substancial em suas dimensões social, econômica, política. Na Constituição brasileira, lida em sua perspectiva transformadora, não há espaço para retrocessos.

De fato, o constitucionalismo transformador buscou encarar a inércia que muitas vezes marcou e ainda marca a atuação dos Executivos e Legislativos latinoamericanos, negligentes com as mudanças necessárias para o enfrentamento da desigualdade. Na visão de Barroso (2016, p. 74): "a legal system that leaves its traditional comfort zone, which is one of conserving relevant political achievements, and begins to embody a promotional function, thus becomes an instrument of social progress". ${ }^{13}$ Os dramas da realidade latino-americana em verdade conclamam uma atuação transformadora de todos os agentes estatais, dentre eles os juízes. Não pode o Judiciário reproduzir uma realidade social de barbárie, mas deve conscientemente reconhecer seu papel de reversão da realidade de violência e discriminação gerada pelo racismo (FLAUZINA; PIRES, 2020, p. 1219).

Nessa perspectiva, a jurisdição constitucional é fortalecida para ser ativista em um sentido materialmente definido: desobstruir os canais necessários à promoção das mudanças dirigidas a uma democracia social. As cortes constitucionais podem assumir o papel de representantes argumentativos dos grupos sociais negligenciados pelos processos políticos tradicionais (ROA ROA, 2020, p. 1, 3).

A centralidade judicial do constitucionalismo transformador requer um pressuposto essencial: o diálogo. Na medida em que as decisões judiciais estruturais demandam ações de múltiplos atores na sociedade, inclusive o desenho de políticas públicas e mesmo produção legislativa, a adoção de um modelo dialógico favoreceria a cooperação desses atores. Além disso, podem ser múltiplas as formas de realizar direitos fundamentais a fim de promover inclusão e combater a desigualdade social. Mecanismos dialógicos permitem, como exemplifica Dixon (2007, p. 408-409) que a corte equilibre a definição do alcance normativo dos direitos com os graus de imposição de medidas administrativas ou legislativas. Seria o caso de colher da participação de outros atores na arena processual indicações de soluções eficazes para realizar

\footnotetext{
13 "Um sistema legal que abandona sua zona de conforto, qual seja, conservar as conquistas políticas relevantes, e passa a incorporar uma função promocional transforma-se, então, em um instrumento de progresso social” (tradução nossa).
} 
conteúdos essenciais dos direitos, para determinar que as soluções encontradas sejam adotadas em prazos definidos e mediante critérios de responsabilização.

O diálogo proposto pelo constitucionalismo transformador se desenvolve em dupla frente. De um lado, um diálogo judicial travado com cortes internacionais e regionais de direitos humanos, o qual tem sido impulsionado pelo movimento do Ius Constitutionale Commune na América Latina, de modo que o diálogo judicial pautado na realização dos direitos humanos, da democracia e do Estado de Direito impulsiona a construção de um direito comum, focado em standards abertos (BOGDANDY, 2016). Nesse diapasão, o diálogo com as cortes internacionais permite operacionalizar compromissos convencionais que orientam uma interpretação e aplicação inclusiva das normas de direitos humanos, de modo que a jurisprudência interamericana construída ao longo dos últimos anos possa contribuir para o desenho de soluções capazes de enfrentar o racismo estrutural ${ }^{14}$, bem como reforçar as obrigações constitucionais, como se viu no caso Favela Nova Brasília vs. Brasil.

De outro, o diálogo com os demais poderes constituídos e com a sociedade civil. No que diz respeito ao diálogo institucional, lembra Dixon (2007, p. 407) que cortes não podem fazer tudo sozinhas, pela mesma razão que não se pode deixar toda a realização do projeto constitucional exclusivamente nas mãos do Legislativo ou do Executivo: elas também podem errar. Ademais, "el hecho de que los jueces asuman la función de impulsar cambios sociales no resuelve todos los problemas, no soluciona todos os dilemas, ni materializa todas las transformaciones que este requiere" 15 (ROA ROA, 2020, p. 7). Por isso, elas precisam trabalhar em regime de cooperação com os demais poderes, sabendo reconhecer oportunidades para deferência a atuações transformadoras do Congresso e do Governo.

Se a corte tem o condão de impulsionar mudanças, deve fazê-lo de forma independente, porém não de forma isolada, pois a transformação de elementos estruturais de uma sociedade, como o racismo, exige uma ação articulada que integre o Legislativo e o Executivo, bem como os movimentos sociais. Nesse sentido o constitucionalismo transformador pode ter caráter cooperativo (jamais conivente), quando a corte é deferente às políticas públicas antidiscriminatórias e promotoras de inclusão (ROA ROA, 2020, p. 7; FOWKES, 2015, p. 21-23; ROUX, 2003, p. 3, 21). Esse foi o caso das ações afirmativas adotadas pelas universidades brasileiras e também da

\footnotetext{
${ }^{14}$ Como se pode verificar no caso Favela Nova Brasília vs. Brasil (2017), que, embora não tenha abordado especificamente o racismo, reconheceu que a violência policial se dirigia ao povo negro, e, no caso Acosta Martínez e outros vs. Argentina (2020), que tratou da prisão e agressão física seguida de morte de um negro, sob a acusação genérica de estar ébrio, como produto da adoção de perfis raciais por agentes policiais em evidência de racismo institucional.

15 "o fato de que os juízes assumem a função de impulsionar as mudanças sociais não resolve todos os problemas, não soluciona todos os dilemas, nem materializa todas as transformações que se requer” (tradução nossa).
} 
Lei $\mathrm{n}^{\circ} 12.990$, de 2014 , que previu uma reserva de $20 \%$ das vagas para cotas raciais em concursos para provimento de cargos na Administração Pública. Nesses casos, o STF desempenhou seu papel transformador chancelando essas práticas (Arguição de Descumprimento de Preceito Fundamental 186/DF e Ação Declaratória de Constitucionalidade 41/DF). ${ }^{16}$

Bem verdade que a Corte constitucional brasileira levou tempo até adotar ações concretas que refletissem o combate ao racismo estrutural, sendo talvez o primeiro impulso o julgamento da ADPF 186 sobre cotas raciais nas universidades. Embora as medidas ali chanceladas estivessem focadas no racismo institucional, podem desencadear mudanças progressivas na estrutura da sociedade. Esse dado reforça a perspectiva de que as mudanças estruturais exigem uma confluência de fatores e podem seguir ritmos variados em cada sociedade, considerando-se também o desenho institucional e político. A sintonia fina de todos esses elementos deve ser calibrada por uma perspectiva dialógica.

Significa que nenhum dos poderes pode ter uma supremacia definitiva na realização do ideal constitucional - se a corte constitucional deve saber encontrar os espaços para deferência, também não se pode confiar cegamente nos processos legislativos. As manobras que marcam os jogos políticos presentes no Legislativo tendem a deixar "pontos cegos" ou sucumbir a uma certa "inércia" nos processos de criação legislativa ou implementação das normas constitucionais. Os "pontos cegos" deixados pelos processos legislativos (i) podem decorrer da ignorância de que leis aplicadas em certos sentidos podem gerar violação de direitos, (ii) podem ser o resultado da criação de leis que deixaram de considerar situações específicas de certos grupos sociais, fazendo com eles não sejam beneficiados pela lei ou, pior, sejam prejudicados por ela, (iii) ou ainda podem decorrer da incapacidade dos legisladores de perceberem como acomodar necessidades legítimas de grupos sociais sem comprometer excessivamente os demais objetivos constitucionais (DIXON, 2007, p. 402). Os "pontos cegos" e a "inércia" são tão comprometedores para a ordem constitucional que justificam a entrada em ação de outros atores - como as cortes constitucionais - a fim de realizar um desbloqueio tanto pelo aspecto discursivo e racional de seus processos quanto pela coercitividade de suas decisões (DIXON, 2007, p. 405). A corte constitucional pode alavancar o reconhecimento de direitos que ficam nos "pontos cegos" de legislativos, enfrentar a inércia decorrente do favorecimento de grupos politicamente mais influentes, e também conter medidas que impliquem retrocesso.

${ }^{16}$ STF, ADPF 186, Tribunal Pleno, Rel. Min. Ricardo Lewandowski, j. 26 abr. 2012; STF, ADC 41, Tribunal Pleno, Rel. Min. Roberto Barroso, j. 8 jun. 2017. 
No caso do racismo estrutural presente no Brasil, estes pontos cegos estiveram presentes durante muitos anos, haja vista que as relações institucionais simplesmente reproduziam a invisibilidade do racismo que conformava as relações sociais em seus mais variados aspectos. Já a inércia decorre da prevalência de interesses eleitorais que se mostram mais prementes, ou da grande conflituosidade de certos temas, gerando um elevado custo político (DIXON, 2007, p. 403). Também a inércia marcou (marca) o enfrentamento do racismo estrutural brasileiro, na medida em que o atendimento de pautas dos movimentos negros dificilmente representa uma prioridade política dos representantes eleitos. Quando essa inércia legislativa é combinada com a inação da Administração Pública, tem-se um quadro nefasto para a realização de direitos, como se verá adiante na incidência da pandemia de Covid-19 entre os povos quilombolas.

Nessa perspectiva, o empoderamento da corte constitucional pelo constitucionalismo transformador implica um reforço da legitimidade de sua atuação, para o que mecanismos processuais colocados à disposição pelo desenho institucional assumem especial relevância, inclusive para propiciar maior diálogo com a sociedade civil. Como salienta Bogdandy (2016), a jurisdição constitucional deve ser um espaço acessível aos cidadãos para que suas demandas legítimas sejam devidamente consideradas.

Além do conteúdo das decisões transformadoras, os tipos de remédios constitucionais, as ações de controle de constitucionalidade e os mecanismos procedimentais internos aos processos podem legitimar sua atuação e contribuir para aperfeiçoar sua função, tornando os julgados dialógicos e efetivos. Para tanto, deve haver transparência nos julgados, preocupação com a compreensão de seu conteúdo pela sociedade civil e pelos agentes estatais mediante técnicas diplomáticas de adjudicação, e, sobretudo, o uso de litígios estruturais que primem por um diálogo institucional (FOWKES, 2015, p. 18-19).

No Brasil, uma maior abertura para a participação da sociedade civil na construção dos julgados se pode verificar em mecanismos como o amicus curiae e o uso de audiências públicas. Eles garantem visibilidade aos interesses em pauta e elevam estratégias de accountability, na medida em que as informações e os argumentos trazidos por esses atores sociais são considerados na fundamentação das sentenças. Ainda que a promoção de autêntico diálogo com a sociedade civil dependa de um aprimoramento desses mecanismos, haja vista que muitas audiências públicas têm sido subaproveitadas pela redução das intervenções ao caráter informativo e vedação aos debates, é possível reconhecer que as informações prestadas em audiências públicas e os amici curiae influenciam os 
julgados (GODOY, 2017, p. 200-202). O potencial desses mecanismos para a legitimação do papel transformador do STF pode e deve ser aprimorado. ${ }^{17}$

Outro mecanismo essencial é o litígio estrutural. Embora seu surgimento seja anterior às constituições potencialmente transformadoras da América Latina e remonte às ações judiciais sobre direitos civis nos Estados Unidos (BROOCKE, 2020, p. 19), certamente é instrumento de legitimação da centralidade judicial presente no constitucionalismo transformador. Nessas modalidades litigiosas verifica-se a participação ativa das comunidades de vítimas de violações de direitos, daqueles a serem responsabilizados diretamente por essas violações, e das instituições a quem compete a construção das soluções. Ainda que os mecanismos de litígio estrutural devam passar por constante aprimoramento (ROA ROA, 2020, p. 8), eles contribuem para o caráter dialógico da atuação jurisdicional, conferindo maior legitimidade à centralidade judicial, esta sim um elemento definidor do constitucionalismo transformador.

Esses mecanismos ganham ainda mais relevância quando se trata de enfrentar o racismo estrutural, na medida em que soluções para processos discriminatórios arraigados ao tecido social e que, muitas vezes, são inconscientes precisam abordar, de forma transparente, as raízes dos conflitos que se materializam na superfície. Tem se avolumado a quantidade de entidades e associações que pleiteiam a participação como amicus curiae em ações que envolvem os efeitos do racismo estrutural, e o processamento desses litígios perante o STF tem assumido o formato dos litígios estruturais, como será abordado no próximo tópico.

Diante da gravidade do racismo estrutural, o constitucionalismo transformador tem muito a agregar. Como o próprio processo constituinte demonstrou, os meios políticos têm limitações que podem prejudicar a efetiva adoção de medidas voltadas para transformações profundas dirigidas ao reconhecimento e à redistribuição de oportunidades para os grupos racializados. A autoridade das decisões judiciais não implica um passe de mágica que transforma o mundo, mas serve de chave que abre portas dirigidas a essa transformação. Por meio de litígios estruturais, a corte constitucional pode convocar os atores institucionais, os movimentos sociais e os cidadãos para a construção de respostas adequadas. O constitucionalismo transformador pauta um ativismo comprometido e materialmente fundado no combate à exclusão.

\footnotetext{
${ }^{17}$ Em estudo crítico sobre as audiências públicas, Lívia Gil Guimarães (2020) indica a necessidade de aprimorar o processo de convocação e a acessibilidade dos grupos interessados bem como o desenho institucional da audiência em si, a fim de promover um espaço autenticamente dialógico. Uma análise mais detida do tema foge, contudo, ao escopo do presente trabalho.
} 


\section{Constitucionalismo transformador para um STF antirracista}

Embora a Constituição Federal tenha sido promulgada em 1988, somente a partir da primeira década dos anos 2000 o tema do racismo chegou ao STF. Em 2003, a Corte decidiu, em sede do Habeas Corpus 82.424 (Caso Elwanger), o racismo veiculado por obra literária: a publicação de livros que insuflavam preconceito contra judeus, inclusive negando fatos históricos. O caso foi relevante para a análise do racismo porque venceu o paradigma biológico para reconhecer a raça como uma categoria histórica, social e política. No lugar da interpretação conservadora e restrita feita pelo relator, Ministro Moreira Alves, para quem a publicação de ofensas ao povo judeu não poderia ser considerada racismo, pois esse povo não pertencia biologicamente a uma raça, o colegiado da Corte seguiu o Ministro Maurício Corrêa para reconhecer “[...] o racismo como tendência cultural, decorrente de construções ideológicas e programas políticos visando a dominação de uma parcela da sociedade sobre outra”. Para que se realizasse o objetivo constitucional de promoção do bem de todos, segundo o relator, “[...] a referência a raça deve[ria] ter conteúdo mais amplo, sob pena de inaceitável inocuidade no que tange a cor" ${ }^{18}$

Naquele mesmo ano, o Inquérito 1.458 trouxe o tema da injúria racial: um tratamento preconceituoso dirigido a um comissário de bordo em razão da sua cor. O relator, Ministro Marco Aurélio, tratou do caso sob um viés declaradamente comprometido com os valores constitucionais e até ativista. Rechaçou uma análise mais técnica e acadêmica do caso para reconhecer a responsabilidade do acusado pela manifestação preconceituosa, considerando "os tempos atuais, que são de mudança cultural". ${ }^{19}$

No Habeas Corpus 86.452, a Corte constitucional chamou a atenção para um caso que não era de injúria simples, mas de injúria racial, pois o acusado teria desrespeitado um homem negro e o acusado maliciosamente de roubar seus óculos. Diante de uma queixa-crime imprecisa, que não especificara a injúria racial, o acórdão se prendeu aos fatos para reconhecer o preconceito manifesto. ${ }^{20}$

\footnotetext{
${ }^{18}$ STF, HC 82.424, Tribunal Pleno, Rel. Min. Moreira Alves, Rel. p/acórdão Min. Maurício Corrêa, j. 17 set. 2003, p. 568-569, 581).

${ }^{19}$ STF, Inq 1.458, Tribunal Pleno, Rel. Min. Marco Aurélio, j. 15 out. 2003, p. 91-92.

${ }^{20}$ STF, HC 86.452, Segunda Turma, Rel. Min. Joaquim Barbosa, j. 7 fev. 2006, p. 218.
} 
Nesses casos, o tema do racismo ainda estava preso ao viés individualista ${ }^{21}$, pois as decisões se dirigiam apenas à análise da presença, ou não, dos elementos aptos a configurar um comportamento voluntário e discriminatório. Porém, já apontava a consciência da necessidade de uma "mudança cultural" a determinar uma leitura transformadora.

O julgamento da ADPF 186, em 2012, representou para o STF a oportunidade de abraçar uma pauta antirracista. ${ }^{22}$ Provocada para declarar contrária à Constituição a instituição de política pública de cotas raciais pela Universidade de Brasília, a Corte se opôs à interpretação conservadora preconizada pela petição inicial e, com respaldo em ampla participação de associações ligadas ao movimento negro, promoveu uma interpretação transformadora da Constituição, a fim de fundamentar a validade das ações afirmativas baseadas em critérios raciais. O Ministro Lewandowski, relator do caso, adotou entendimento inequivocamente preocupado com o racismo enraizado na estrutura social brasileira, ao observar que o baixo número de negros e pardos nas universidades e mesmo nos cargos públicos ou privados de maior relevo social decorria de uma discriminação histórica e intergeracional. Nesse diapasão, as ações afirmativas adotadas pelas instituições de ensino representavam "uma forma de compensar essa discriminação, culturalmente arraigada, não raro, praticada de forma inconsciente e à sombra de um Estado complacente". ${ }^{23}$ Cabia ao Estado abandonar a inércia e contar com o apoio da Corte constitucional contra movimentos mais conservadores da sociedade. As ações afirmativas defendidas naquela oportunidade tinham um importante significado estratégico para o enfrentamento do racismo: criam-se líderes nos grupos discriminados, habilitados a defender seus direitos e servir de exemplo de integração e ascensão social. Além disso, confirma-se a necessidade de políticas públicas focadas no reconhecimento da cidadania dos povos discriminados, para além da distribuição material de bens e serviços. ${ }^{24}$

\footnotetext{
${ }^{21} \mathrm{O}$ tema do racismo individualista não deixou de ser tratado pelo STF, nas hipóteses de racismo, injúria racial e racismo religioso (HC 180.132 AgR, RHC 134.682, ARE 1.136.770, ARE 692.330, Inq. 1.458, HC 109.676, RHC 146.303). Digno de menção foi o julgamento do Inquérito 4.694 contra o atual presidente da República, a quem foi imputado crime de racismo em discurso proferido em 2017, no exercício do cargo de deputado federal. A Primeira Turma do STF entendeu que não teria havido crime pela falta do elemento comportamental do dolo no sentido de gerar discriminação e pelo discurso proferido estar guarido na figura da imunidade parlamentar (voto do rel. Min. Marco Aurélio). Houve divergência do Min. Roberto Barroso e da Min. Rosa Weber (STF, Inq 4.694, Primeira Turma, Rel. Min. Marco Aurélio, j. 11 set. 2018).

${ }^{22} \mathrm{Na}$ mesma linha a ADI 3.330, que reconheceu a constitucionalidade do Programa Universidade para Todos (Prouni) como ação afirmativa capaz de enfrentar a desigualdade social, sobretudo aquela dirigida a negros e índios (STF, ADI 3.330, Tribunal Pleno, Rel. Min. Ayres Britto, j. 3 mai. 2012).
}

${ }^{23}$ STF, ADPF 186, Tribunal Pleno, Rel. Min. Ricardo Lewandowski, j. 26 abr. 2012, p. 66-67.

${ }^{24}$ STF, ADPF 186, Tribunal Pleno, Rel. Min. Ricardo Lewandowski, j. 26 abr. 2012, p. 72. 
Saliente-se um cuidado tomado pelo STF: ainda que tenha reconhecido a validade da política de cotas raciais adotada pelas universidades, não tomou o lugar do legislador nem invadiu - com a fixação de obrigatoriedade - a autonomia universitária. Manteve-se aberto o espaço de diálogo, reconhecendo que caberia à lei tratar da obrigatoriedade das cotas ou dos critérios para sua execução. ${ }^{25}$

Anos mais tarde, o STF voltou ao tema das cotas no julgamento da Ação Declaratória de Constitucionalidade 41, de 2017, de relatoria do Ministro Luís Roberto Barroso. Também nessa oportunidade referendou a constitucionalidade da Lei $\mathrm{n}^{\circ} 12.990$, de 2014 , que instituiu a reserva de $20 \%$ das vagas em concursos públicos para cargos efetivos e empregos na administração pública direta e indireta, a partir do critério de autodeclaração. O voto do Ministro Barroso transpareceu a preocupação em aprofundar a análise do racismo para além dos comportamentos discriminatórios, de modo que as instituições - como as leis e a própria Corte constitucional - assumissem um papel ativo:

[...] aqui o racismo era tão estruturalmente arraigado que isso já acontecia naturalmente, independente de lei, como consequência da marginalização e do próprio sentimento de inferioridade que isso criava. Nós nos acostumamos com uma sociedade em que os negros eram tratados de uma maneira estratificada, hierarquicamente inferiores nas atividades que desempenhavam. [...] Logo, é impossível alguém imaginar que é possível sair de um estado de coisas estruturalmente desfavorável como esse sem algum tipo de apoio institucional. ${ }^{26}$

Essa também foi a tônica da fundamentação adotada pelo STF em julgamento cautelar da ADPF 738, que determinou a destinação de recursos do fundo eleitoral para as candidaturas de negros e pardos nas eleições municipais de 2020. O ativismo da Corte constitucional nesse caso se fez presente na medida cautelar que determinou a produção de efeitos da distribuição de recursos com vigência já para o processo eleitoral do mesmo ano, inclusive convalidando uma diretriz de ação afirmativa que partia da função regulatória do Tribunal Superior Eleitoral, e não propriamente do Congresso brasileiro. Como bem observou o STF, “[...] não basta não discriminar. A postura, agora, é, acima de tudo, de implemento de medidas direcionadas a viabilizar oportunidades". ${ }^{27-28}$

\footnotetext{
${ }^{25}$ STF, ADPF 186, Tribunal Pleno, Rel. Min. Ricardo Lewandowski, j. 26 abr. 2012, p. 115.

${ }^{26}$ STF, ADC 41, Tribunal Pleno, Rel. Min. Roberto Barroso, j. 8 jun. 2017, p. 20.

${ }^{27}$ STF, ADPF 738 MC-Ref, Tribunal Pleno, Rel. Min. Ricardo Lewandowski, j. 26 out. 2020, p. 17-18.

${ }^{28}$ Ressalte-se que a posição adotada pelo STF não foi unânime. O Ministro Marco Aurélio divergiu para declarar que ações
} 
Ao procurar transformar a forma como o direito, a Administração Pública, a Universidade e as eleições tratam a condição dos grupos racializados, é possível reconhecer que a própria sociedade passa a sofrer transformações em sua estrutura. Quebra-se um ciclo vicioso que perpetua a discriminação e a exclusão social. Ainda que o racismo seja enfrentado na dimensão institucional, posturas ativas como as mencionadas repercutem no racismo estrutural.

Houve um caso, contudo, em que o STF teve oportunidade de fomentar o combate ao racismo estrutural pela via da ação estatal nos casos de contratação de pessoas jurídicas pelas vias de licitação, mas adotou posição tímida, fazendo uma interpretação conservadora da Constituição. No julgamento da ADI 3.092, o Ministro Relator Marco Aurélio reconheceu a inconstitucionalidade de uma lei do Estado de São Paulo que proibia a Administração Pública de contratar empresas que tivessem, em seus quadros, funcionários ou dirigentes condenados por práticas discriminatórias, inclusive racismo. A maioria acompanhou o relator para entender que a norma era inconstitucional, pois violava a intransmissibilidade da pena, gerando inclusive um gravame desproporcional para a pessoa jurídica. Ressalte-se, no entanto, o voto divergente do Ministro Edson Fachin, que declarou constitucional a lei no entendimento de que a mesma "[...] reforça[ria] a proteção dos direitos fundamentais das vítimas de tais crimes e cumpre o mandamento constitucional que não autoriza tolerar o sofrimento que a discriminação impõe". ${ }^{29}$ Se a perspectiva transformadora tivesse sido adotada para além do voto divergente, possivelmente o resultado desse caso teria sido diverso.

Entretanto, ainda que a leitura inclusiva proposta pelo constitucionalismo transformador encontre avanços e reticências, pode-se perceber que a jurisdição constitucional brasileira tem tido oportunidade de exercer um papel transformador no sentido de interpretar a Constituição e confirmar as boas práticas adotadas pelas outras instituições, declarando a constitucionalidade de leis e políticas públicas que enfrentavam o racismo pelo viés distributivo e de reconhecimento. Em tempos de cooperação institucional, o constitucionalismo transformador implica uma jurisdição constitucional capaz de contribuir com interpretações das normas legais e constitucionais que pavimentem um caminho seguro para as mudanças desencadeadas pelos demais atores sociais, desde que dirigidas à inclusão social. E as oportunidades que chegam à Corte precisam ser aproveitadas a fim de enfraquecer

afirmativas deveriam ser determinadas pelo legislador (STF, ADPF 738 MC-Ref, Tribunal Pleno, Rel. Min. Ricardo Lewandowski, j. 26 out. 2020, p. 24-25).

${ }^{29}$ STF, ADI 3.092, Tribunal Pleno, Rel. Min. Marco Aurélio, j. 22 jun. 2020, p. 18. 
os efeitos deletérios gerados pelo racismo estrutural e impulsionar mudanças mais profundas. Uma atuação proativa e comprometida com a inclusão pela jurisdição constitucional permite dar voz aos grupos antes discriminados, bem como contribuir para a formação de novos consensos (ALMEIDA, 2020, p. 147).

No entanto, o racismo estrutural no Brasil, muitas vezes, desafia uma atuação mais proativa da jurisdição constitucional, haja vista que as discriminações mais arraigadas da estrutura social vêm à tona para gerar o descarte de vidas negras. O tema da necropolítica (MBEMBE, 2018) que atinge o povo negro tem sido dissimulado há muitos anos e compõe um elemento cruel do racismo estrutural. Ele se evidencia na estrutura do sistema carcerário brasileiro, na letalidade das forças policiais, no tornar invisível o extermínio de quilombolas durante a pandemia de Covid-19 decorrente da omissão Estatal.

Enfrentar essa realidade exige que o STF aproveite as oportunidades decorrentes da provocação cidadã de sua jurisdição e adote soluções capazes de combater os efeitos do racismo estrutural a partir do enfrentamento de suas causas, suas raízes. Uma análise dessa amplitude deve também ser dialógica.

O primeiro litígio estrutural que enfrentou a temática do racismo foi a ADPF 347 , e reconheceu o estado de coisas inconstitucional do sistema prisional brasileiro. Esse caso foi o primeiro a buscar uma abordagem mais completa (e complexa) do racismo estrutural a partir do reconhecimento de que o sistema prisional encarcera majoritariamente negros, pardos e pobres. ${ }^{30}$ Ainda que o enfrentamento do racismo estrutural não tenha sido a preocupação central da cautelar concedida (a esse aspecto se pode atribuir a crítica de que foram insatisfatórias), é preciso reconhecer que a Corte demonstrou estar consciente de que as medidas ali adotadas repercutiriam mesmo que timidamente - nesse tema.

A ação visava coibir o Executivo a apresentar um plano de ação para superar, em definitivo (no prazo de três anos), o quadro de violação de direitos caracterizado como inconstitucional, o qual contemplasse alternativas para o encarceramento excessivo, acabasse com a superlotação, fizesse a adequação das instalações prisionais aos padrões normativos, e eliminasse a tortura, entre outros pedidos. A pretensão vinha no sentido de promover uma reforma profunda no sistema, e o Supremo Tribunal Federal se reconheceu, como se depreende do voto do Ministro Relator Marco Aurélio, à altura do desafio para superar os entraves políticos e institucionais bloqueadores da criação e implementação de soluções efetivas. À inércia dos demais poderes, obstruindo os

${ }^{30}$ STF, ADPF 347 MC, Tribunal Pleno, Rel. Min. Marco Aurélio, j. 9 set. 2015, p. 22. 
canais democráticos, não poderia se somar a inércia da jurisdição constitucional, pois assim estaria barrada a efetividade da própria Constituição e dos Tratados Internacionais sobre Direitos Humanos. ${ }^{31}$

Nesse diapasão, a Corte constitucional reconheceu que os presos não têm representatividade política nem mesmo visibilidade social. Não elegem, não são eleitos, a opinião pública não se preocupa com sua condição. ${ }^{32}$ Embora essa realidade fosse decorrente do racismo estrutural - essa dimensão mais radical ficou longe de ser apreciada. A missão transformadora que se demandou do STF, nesse caso, não foi desempenhada para gerar soluções estruturais mais profundas.

O reconhecimento cautelar do Estado de Coisas Inconstitucional implicou observar que todos os poderes do Estado eram responsáveis por aquela realidade de violência, inclusive o Judiciário em virtude da "cultura do encarceramento". Nesse diapasão, as transformações deveriam vir de uma autocrítica das próprias instituições judiciais, como assinalou em seu voto o Ministro Gilmar Mendes. ${ }^{33}$ As soluções identificadas na medida cautelar, embora significativas, foram singelas no tocante às responsabilidades do Judiciário e do Executivo: (i) a exigência de fundamentação judicial para a não aplicação de penas alternativas ao encarceramento; (ii) a aplicação das diretrizes da Convenção Americana sobre Direitos Humanos para a realização de audiências de custódia; (iii) o dever de considerar o Estado de Coisas Inconstitucional do sistema prisional quando os juízes se depararem com a previsão legal de penas privativas de liberdade, devendo favorecer a aplicação de penas alternativas; (iv) descontigenciamento de verbas do Fundo Penitenciário Nacional para o seu efetivo emprego, segundo o fim para o qual foi criado. ${ }^{34}$

Flauzina e Pires (2020, p. 1224-1125) entendem que o STF acabou por referendar um sistema produto e produtor de racismo, blindando o Judiciário de sua efetiva responsabilidade. Para as autoras, se o sistema carcerário produz violação de direitos, não cabe mais o encarceramento. Soluções drásticas produzidas na esfera judicial, contudo, se, de um lado, têm potencial transformador, de outro, podem gerar "backlash". Ao que parece, o STF foi tímido para ser "diplomático", mantendo portas abertas para um diálogo institucional com soluções a serem construídas no longo prazo. Para Flauzina e Pires (2020), ele foi tímido porque foi conivente.

\footnotetext{
${ }^{31}$ STF, ADPF 347 MC, Tribunal Pleno, Rel. Min. Marco Aurélio, j. 9 set. 2015, p. 31.

${ }^{32}$ STF, ADPF 347 MC, Tribunal Pleno, Rel. Min. Marco Aurélio, j. 9 set. 2015, p. 21.

${ }^{33}$ STF, ADPF 347 MC, Tribunal Pleno, Rel. Min. Marco Aurélio, j. 9 set. 2015, p. 137.

${ }^{34}$ STF, ADPF 347 MC, Tribunal Pleno, Rel. Min. Marco Aurélio, j. 9 set. 2015, p. 41-42.
} 
A ação permanece em trâmite, com a participação dos entes da federação que prestaram informações sobre a realidade de suas penitenciárias e os planos adotados para realizar melhorias. Muito se espera dessa ADPF, que propõe um litígio estrutural complexo e com significativo potencial transformador (BROOCKE, 2020, p. 171). Essa potência, contudo, precisa se concretizar. Para efeitos de combate ao racismo estrutural, ainda é necessário enfrentar a estrutura penal que favorece o encarceramento e a inércia da Administração Pública para com a proteção dos direitos das pessoas encarceradas.

Na ADPF 635, também pendente de julgamento do mérito, o tema enfrentado são as graves violações de direitos humanos ocorridas durante as intervenções policiais no Estado do Rio de Janeiro, que revelam o racismo estrutural nas forças de segurança pública. Como narrado na liminar deferida pelo Ministro Luiz Edson Fachin, as medidas que implicam invasão de domicílio, prisão arbitrária e execução sumária atingem desproporcionalmente a população negra, já que 67\% dos moradores das comunidades pobres alvo das operações policiais no Rio de Janeiro são negros. ${ }^{35}$

Em 5 de junho, o relator deferiu medida liminar que atentava para um aditamento da petição inicial: para além dos direitos diuturnamente violados, a pandemia estaria agravando a situação, especialmente no que tocava à letalidade de crianças e jovens que estariam em casa em virtude das medidas de isolamento social. Nesse caso, a liminar foi concedida para que “[...] sob pena de responsabilização civil e criminal, não se realizem operações policiais em comunidades do Rio de Janeiro durante a epidemia da Covid-19, salvo em hipóteses absolutamente excepcionais, que devem ser devidamente justificadas por escrito pela autoridade competente [...]”. ${ }^{36} \mathrm{~A}$ medida não teria impossibilitado a realização de medidas policiais, invadindo esfera de atuação do Executivo, mas condicionado referidas medidas a protocolos básicos de segurança para a salvaguarda dos direitos humanos das pessoas envolvidas.

Como deixou evidente o Ministro Gilmar Mendes em seu voto, o racismo estrutural estava no fundamento da decisão da corte, já que a letalidade policial no Rio de Janeiro estava marcada pela identificação racial de suas vítimas:

O racismo estrutural da sociedade se revela potencializado nas mortes ocasionadas pelas forças policiais. Isso porque "o racismo se constitui não apenas como uma causa de exclusão ou de empobrecimento das pessoas negras; pelo contrário, o racismo caracteriza-se sobretudo como um fenômeno que promove a desumanização das pessoas negras

\footnotetext{
${ }^{35}$ STF, ADPF 635 MC-TPI, Decisão Monocrática, Rel. Min. Edson Fachin, j. 5 jun. 2020.

${ }^{36}$ STF, ADPF 635 MC-TPI-Ref, Tribunal Pleno, Rel. Min. Edson Fachin, j. 5 ago. 2020, p. 30.
} 
e que produz vantagens e benefícios sociais para os integrantes do grupo racial hegemônico". Desse modo, "não é possível pensar as formas de controle e administração dos conflitos na sociedade afastando a análise do papel cognitivo do racismo enquanto elemento articulador das maneiras de pensar os problemas sociais e de formular as respostas para essas questões políticas" (FREITAS, Felipe da Silva. Racismo e polícia: uma discussão sobre mandato policial. Tese de Doutorado. Universidade de Brasília, 2020. p. 171). ${ }^{37}$

Ademais, com se extrai do voto então proferido pelo Ministro Gilmar Mendes, o tema precisaria ser tratado na roupagem dos litígios estruturais, em que a intervenção do Judiciário quebraria a inércia do Executivo, já que sua omissão implicava "omissão inconstitucional prolongada e insustentável”, bem como havia "urgência e necessidade da intervenção judicial". ${ }^{8}$ Porém, mesmo em sede de julgamento sumário, é possível identificar que a Corte ousou ir um pouco mais longe que no julgamento da ADPF 347. Uma vez identificada a letalidade das forças de polícia atingindo de forma discriminatória a população negra e pobre durante a pandemia, que as operações fossem reduzidas drasticamente e, se extremamente necessárias, justificadas com transparência.

Em julgamento da medida cautelar, o STF assumiu uma posição comprometida com a análise mais radical do problema que lhe fora apresentado, porém sem enfrentar questões como um plano de política pública para enfrentar a letalidade policial - embora o Ministro Gilmar Mendes tenha alertado para a sua necessidade, já que, desde a condenação do Estado brasileiro pela Corte Interamericana no caso Favela Nova Brasília, nada havia sido feito para conter a evidência e a persistência das violações.

Vencido o Ministro Gilmar Mendes, o STF determinou, entre outros, um uso justificado e proporcional dos meios físicos (como helicópteros) postos à disposição das forças de segurança pública, segundo os parâmetros internacionais; a realização de um relatório detalhado pelas autoridades competentes ao final de cada operação policial como medida de accountability no plano judicial e administrativo, permitindo a responsabilização de agentes envolvidos em crimes; a orientação dos agentes de segurança e profissionais da saúde para preservar vestígios de crimes praticados em operações policiais; a documentação por fotografia das provas periciais; a absoluta

\footnotetext{
${ }^{37}$ STF, ADPF 635 MC-TPI-Ref, Tribunal Pleno, Rel. Min. Edson Fachin, j. 5 ago. 2020, p. 37.

${ }^{38}$ STF, ADPF 635 MC-TPI-Ref, Tribunal Pleno, Rel. Min. Edson Fachin, j. 5 ago. 2020, p. 45.
} 
excepcionalidade de operações policiais no perímetro de escolas e a proibição do uso de escolas como bases operacionais; a investigação pelo Ministério Público da suspeita de prática criminosa por agentes de segurança. Como salvaguarda para essa postura de cunho mais ativista, alinhando-se ao constitucionalismo transformador, o STF observou que a “[...] separação estanque de funções estatais por vezes se confunde, uma vez que diversas questões de direitos estão umbilicalmente conectadas com questões de políticas. [...] tais questões podem ser decididas em fóruns políticos superpostos e diversamente representativos, incluindo o Poder Judiciário." ${ }^{39}$

Todavia, apesar da decisão cautelar, as operações policiais seguem se realizando, com mortes e impunidade, como o partido requerente denunciou ao STF. Diante do quadro de descumprimento - já que ficou evidenciado que as operações policiais não estavam seguindo os requisitos internacionais demandados pelo STF -, em 17 de dezembro nova decisão foi adotada. Para enfrentar o problema que se mantinha, o STF decidiu convocar audiência pública: o diálogo com as outras instituições e a sociedade civil para a construção de medidas que sejam efetivamente transformadoras: "[...] pretende-se a abertura de um espaço que promova, por meio de um diálogo aberto e plural, esclarecimentos técnicos, outros olhares e pontos de vista sobre a questão, para que se possam colher mais subsídios para o deslinde da controvérsia ora posta". ${ }^{40} \mathrm{~A}$ fim de pautar a audiência pública, tornando-a produtiva, a decisão ainda tomou o cuidado de indicar várias perguntas a serem respondidas pelas entidades que pretenderem participar, todas dirigidas à construção de um plano de contenção da letalidade policial.

Assim, especialmente nesse caso, as decisões adotadas pelo STF encaminham dois diálogos preconizados pelo constitucionalismo transformador em sua vertente dialógica. No campo interno, dispôs-se a um diálogo com a sociedade civil e com as instituições mediante instauração de audiência pública para tratar do tema. No campo jurídico internacional, estabeleceu o diálogo judicial necessário com a Corte Interamericana de Direitos Humanos em virtude da vinculação do Estado brasileiro à sentença condenatória proferida no caso Favela Nova Brasília, em 2017.

Finalmente, outro caso em trâmite perante o STF com potencial de enfrentamento transformador do racismo estrutural é a ADPF 742, proposta pela Coordenação Nacional de Articulação das Comunidades Negras Rurais Quilombolas (Conaq) e pelos partidos políticos Partido Socialista Brasileiro (PSB),

\footnotetext{
${ }^{39}$ STF, ADPF 635 MC-TPI-Ref, Tribunal Pleno, Rel. Min. Edson Fachin, j. 5 ago. 2020, p. 45

${ }^{40}$ STF, ADPF 635, Decisão Monocrática, Rel. Min. Edson Fachin, j. 17 dez. 2020, p. 21.
} 
Partido Socialismo e Liberdade (PSOL), Partido Comunista do Brasil (PC do B), Rede Sustentabilidade e Partido dos Trabalhadores (PT). ${ }^{41}$ A ação visa responsabilizar o Estado por ações e omissões que geraram (e geram) o aumento do número de casos de Covid-19 e consequentes óbitos nas comunidades quilombolas. Essas comunidades vivem à margem da sociedade e têm difícil acesso às redes de saúde e assistência. Solicitam com maior urgência providências como distribuição de água potável, produtos de higiene e equipamentos de proteção individual, bem como medidas que garantam sua segurança alimentar e nutricional. Pedem também que a divulgação dos casos e óbitos em virtude da Covid-19 observe o recorte racial, informando raça e cor das vítimas, bem como seu pertencimento a comunidades quilombolas. Em definitivo, demandam a elaboração de um plano nacional destinado à sua proteção, formado por um grupo interdisciplinar composto de entidades estatais, associações civis e representantes dos quilombolas (PIRES, 2020).

Até a conclusão da redação desse estudo, a Arguição de Descumprimento de Preceito Fundamental 742 estava pautada para julgamento no plenário virtual do STF. Até o momento, o Ministro Marco Aurélio, relator, proferiu voto reconhecendo parcialmente os pedidos formulados: (i) deferiu a inclusão dos dados de vítimas quilombolas nos registros oficiais da pandemia; (ii) determinou a criação de um grupo de trabalho, em 72 horas, do qual participe a Conaq para debater, aprovar e monitorar plano de ações referentes a situação dos quilombolas durante a pandemia; (iii) determinou a elaboração de um plano de enfrentamento da pandemia com prioridade de vacinação para quilombolas, no prazo de 30 dias. Segundo o Conaq, um dos pontos centrais não foi contemplado pelo voto do relator: a fiscalização e o monitoramento das ações conjuntas para elaboração dos planos pelo Poder Judiciário (CRISÓSTOMO, 2021).

Essa omissão certamente compromete a eficácia da decisão, já que o Governo Federal, em momento algum, se mostrou sensível aos direitos desse grupo social. De fato, o enfrentamento do racismo estrutural exige uma atuação compromissada da Corte constitucional, atenta ao cumprimento de suas decisões a fim de gerar efetividade. Exige, ademais, que a Corte promova uma (auto)reflexão de seu papel transformador, a começar pela transformação da forma como deve abordar o racismo estrutural. Não se trata de um problema dos grupos racializados, mas uma realidade

\footnotetext{
${ }^{41}$ Paralelamente a essa ação e discutindo problema análogo que envolve o racismo estrutural dirigido aos indígenas, foi proposta a Arguição de Descumprimento de Preceito Fundamental 709, que trata da proteção dos direitos dos povos indígenas em virtude de condutas omissivas do Estado, que não impedem a afronta às suas terras e a contaminação com a Covid-19, além da falta de cuidados e desrespeito aos cuidados de saúde desses povos, bem como a sua cultura. Apesar de medida cautelar deferida pelo relator, Ministro Roberto Barroso, a falta de compromisso do Estado tem se mostrado patente (STF, ADPF 709 MC-Ref, Tribunal Pleno, Rel. Min. Roberto Barroso, j. 5 ago. 2020).
} 
de violação de direitos pela qual todos somos responsáveis. Como bem observou Almeida (2020, p. 52) “[...] a mudança da sociedade não se faz apenas com denúncias ou com o repúdio moral do racismo: depende, antes de tudo, da tomada de posturas e da adoção de práticas antirracistas”.

\section{Conclusão}

A sociedade brasileira é racista. Formou-se, assim, a partir dos séculos de escravidão, de modo que a discriminação do povo negro não é ocasional nem mesmo voluntária, mas normalizada como um dado de existência da própria forma como essa sociedade se estrutura. A partir dessa constatação, o racismo estrutural impregna as instituições. Essa constatação, todavia, não deve levar ao fatalismo conformado com uma realidade que produz exclusão, violência e morte. Esses efeitos podem ser combatidos a partir de uma ordem normativa que comande processos em sentido oposto: inclusão, dignidade, vida. O direito não pode tudo, mas pode muito.

Nesse contexto e partindo da premissa normativa já afirmada, este estudo defende que o constitucionalismo transformador representa uma ferramenta importante à disposição do STF, a fim de orientar a construção de decisões comprometidas com o enfrentamento das barreiras sociais, políticas e econômicas que contribuem para a manutenção do racismo estrutural. Mediante uma leitura que potencializa a implementação das normas constitucionais, o constitucionalismo transformador fortalece o STF como corte constitucional, dele cobrando uma atuação institucional vocacionada em alavancar as mudanças que se encontram obstruídas no meio político e dar voz e espaço aos grupos tornados invisíveis em virtude da raça. A centralidade jurisdicional, no entanto, deve ser compatibilizada com uma cooperação da Corte para com os avanços transformadores que venham de outras searas - como o caso das ações afirmativas que foram transformadas em leis e políticas públicas como conquistas do movimento negro. O constitucionalismo transformador pode ser um projeto cooperativo que saiba inovar em ambientes conservadores, a fim de promover inclusão e conservar as conquistas colocadas em perigo em momentos políticos de retrocesso.

Contudo, existem casos de violações tão atrozes que inibem ou silenciam grupos oprimidos. Elas podem decorrer tanto de pontos cegos da legislação e do administrador que se abstraem da realidade sob o manto da igualdade formal, ou mesmo de sua inércia diante de pautas políticas julgadas mais vantajosas. No caso do racismo estrutural, tanto os pontos cegos como a inércia dos poderes públicos são reflexos de uma estrutura social que nega relevância aos grupos racializados. Cabe ao STF gerar as condições para que as soluções para a realização do projeto constitucional 
se produzam. Quando os processos políticos para realização dos direitos humanos e combate à desigualdade são bloqueados, a adoção de uma postura antirracista pelo STF representa uma alternativa valiosa, ainda que existam limites a serem superados no desenho institucional.

Esse ativismo judicial transformador, contudo, tem um custo de legitimação. Ele deve estar pautado materialmente para ações progressistas de combate à exclusão e promoção da igualdade substancial. No contexto brasileiro, é necessário defender avanços democráticos já conquistados pelos grupos racializados e impedir retrocessos. Outro aspecto central: o constitucionalismo transformador deve ser dialógico, a fim de favorecer as transformações propostas pelas decisões judiciais, bem como para legitimar a sua construção. Assim, a construção das soluções deve contar com a efetiva participação dos grupos sociais interessados e de todas as instituições envolvidas. Transformações efetivas não se fazem isoladamente, de modo que as portas para o Legislativo, o Executivo, os órgãos de defesa da cidadania e mesmo para a sociedade devem permanecer abertas para fomentar uma cooperação na construção dialogada das decisões. O ambiente dialógico interno proposto por Roa Roa para o constitucionalismo transformador promove maior legitimação dos desbloqueios promovidos pelas decisões judiciais que enfrentam mais radicalmente o racismo estrutural, bem como contribui para que essas decisões colham informações sobre as boas práticas legislativas e governamentais. Quanto mais radical for a decisão no combate ao racismo estrutural, maior o custo de legitimação dialógica.

Mais além, esse diálogo deve ser celebrado com outra corte que será acionada caso o Estado venha a falhar: a Corte Interamericana de Direitos Humanos. A legitimação das decisões do STF também procede de sua conexão com o corpus iuris interamericano, ou seja, com as convenções de direitos humanos e a jurisprudência interamericana.

A partir da análise dos casos que chegaram ao STF sobre o racismo, percebeuse que essa atitude transformadora já era germinada desde o primeiro momento, mas tem sido potencializada pelos litígios estruturais que versam sobre quadros sociais mais complexos, decorrentes do racismo estrutural.

Num primeiro momento, os casos que chegaram ao STF tratavam do racismo individualista, aquele criminalizado em virtude de comportamentos discriminatórios. Ainda que a Corte tenha interpretado as normas constitucionais para responsabilizar essas práticas, o enfrentamento do racismo estrutural precisa ir além da responsabilização individual. As oportunidades para esse enfrentamento têm chegado ao STF, pela provocação de diversos atores sociais. Nos casos das cotas raciais nas universidades, do acesso aos cargos públicos e da destinação de recursos 
do fundo eleitoral às candidaturas negras, as normas constitucionais receberam interpretação transformadora para combater o racismo - num primeiro momento, o racismo institucional, mas com efeitos estruturais. Existem, contudo, momentos em que houve uma contenção conservadora, como no caso da ADI 3.092. ${ }^{42} \mathrm{~A}$ disposição em adotar uma postura transformadora não está dada, mas pode ser construída progressivamente a cada acórdão.

O potencial transformador do STF tem sido testado, ainda, nos litígios estruturais propostos por partidos políticos e associações civis, denunciando o racismo estrutural na sua roupagem mais perversa, qual seja, a manifestação da necropolítica que descarta vidas negras. Para decidir sobre o Estado de Coisas Inconstitucional vigente no sistema prisional brasileiro (ADPF 347), a letalidade das forças de polícia no Rio de Janeiro (ADPF 635) e a proteção das comunidades quilombolas diante do descaso dos poderes públicos durante a pandemia de Covid-19 (ADPF 742), o STF deve abrir caminhos novos.

Na perspectiva transformadora, cabe ao STF atentar para o enfrentamento das causas mais radicais da violência: a razão do encarceramento excessivo; a letalidade policial que atinge majoritariamente negros e pardos pobres; e a invisibilidade de quilombolas desassistidos durante a pandemia. No caso da ADPF 347, andou bem o STF, ao determinar o cumprimento das obrigações convencionais assumidas pelo Brasil e instituir as audiências de custódia, ${ }^{43}$ assim como, na ADPF $635,{ }^{44}$ ao determinar a suspensão das operações policiais nas comunidades no Rio de Janeiro, salvo sua premente essencialidade, e impor os limites traçados no plano internacional para a idoneidade das operações policiais. Ações como essas demandam uma atuação constante, incisiva e estratégica. A inércia judicial não deixa de ser mais uma inércia institucional que (re)produz o racismo estrutural.

Desse modo, se o constitucionalismo transformador é uma ferramenta preciosa que empodera a corte constitucional, é preciso que a sociedade civil permaneça vigilante, dele cobrando uma atuação sincera e comprometida. E talvez, para isso, caiba ao próprio STF uma autorreflexão para que não seja ele um agente inconsciente do racismo estrutural que se comprometeu a combater.

\footnotetext{
${ }^{42}$ STF, ADI 3.092, Tribunal Pleno, Rel. Min. Marco Aurélio, j. 22 jun. 2020.

${ }^{43}$ STF, ADPF 347 MC, Tribunal Pleno, Rel. Min. Marco Aurélio, j. 9 set. 2015.

${ }^{44}$ STF, ADPF 635 MC-TPI-Ref, Tribunal Pleno, Rel. Min. Edson Fachin, j. 5 ago. 2020.
} 


\section{Referências}

ALMEIDA, Sílvio Luiz de. Racismo estrutural. São Paulo: Sueli Carneiro: Jandaíra, 2020.

ANUÁRIO Brasileiro de Segurança Pública 2020. Fórum Brasileiro de Segurança Pública, v. 14, 2020. Disponível em: https://forumseguranca.org.br/wp-content/uploads/2020/10/ anuario-14-2020-v1-interativo.pdf. Acesso em: 8 fev. 2021.

BARROSO, Luís Roberto. Reason without vote: the representative and majoritarian function of constitutional courts. In: BUSTAMANTE, Thomas; GONÇALVES FERNANDES, Bernardo. Democratizing constitutional law: perspectives on legal theory and the legitimacy of constitutionalism. Dordrecht, Suiza: Springer, 2016. p. 71-90.

BERSANI, Humberto. Aportes teóricos e reflexões sobre o racismo estrutural no Brasil. Extraprensa, São Paulo, v. 11, n. 2, p. 175-196, jan./jun. 2018.

BOGDANDY, Armin von. Ius Constitutionale Commune na América Latina: uma reflexão sobre um constitucionalismo transformador. In: BOGDANDY, Armin von; MORALES ANTONIAZZI, Mariela; PIOVESAN, Flávia (coord.). Ius Constitutionale Commune na América Latina: marco conceptual. Curitiba: Juruá, 2016. v. 1. p. 11-51.

BRASKEM. Diversidade no Congresso: veja quem são os eleitos pelo voto no Brasil. Bluevision, Desenvolvimento Humano. 19 fev. 2019. Disponível em: https://bluevisionbraskem.com/ desenvolvimento-humano/diversidade-no-congresso-veja-quem-sao-os-eleitos-pelo-votono-brasil/. Acesso em: 9 fev. 2021.

BROOCKE, Bianca M. Schneider van der. Estado de coisas inconstitucional e managerial judging: gestão judicial ativa e dialógica nos litígios estruturais. 2020. $203 \mathrm{f}$. Tese (Doutorado em Direito) - Pontifícia Universidade Católica do Paraná, Curitiba, 2020.

CRISÓSTOMO, Maryellen. ADPF 742: voto favorável do relator não contempla todas as demandas da população quilombola manifestas na ação. Conaq, 12 fev. [2021]. Disponível em: https://conaq.org.br/noticias/adpf-742-em-julgamento//. Acesso em: 18 fev. 2021.

DIXON, Rosalind. Creating dialogue about socioeconomic rights: strong-form versus weak-form judicial review revisited. International Journal of Constitutional Law, v. 5, n. 3, p. 391-418, 2007.

FLAUZINA, Ana; PIRES, Thula. Supremo Tribunal Federal e a naturalização da barbárie. Revista Direito e Praxis, Rio de Janeiro, v. 11, n. 2, p. 1211-1237, 2020. Disponível em: https:// www.scielo.br/scielo.php?script=sci_arttext\&pid=S2179-89662020000201211\&tlng=pt.

Acesso em: 15 abr. 2021.

FRASER, Nancy. From redistribution to recognition?: dilemmas of justice in a 'post-socialist' age. New Left Review, p. 68-149, 1995. Disponível em: https://bibliopreta.com.br/wp-content/ uploads/2018/01/Fraser-Redistribution-Recognition-Dilema-1.pdf. Acesso em: 10 fev. 2021. 
FREDMAN, Sandra. Substantive equality revisited. International Journal of Constitutional Law, v. 14, n. 3, p. 712-773, 2016. Disponível em: https://doi.org/10.1093/icon/mow043. Acesso em: 10 fev. 2021.

FOWKES, James. Transformative constitutionalism and the global south: the view from South Africa (October 3, 2015). In: VON BOGDANDY, Arnim; FERRER, Eduardo; MORALES, Mariela; PIOVESAN, Flavia (ed.). Transformative constitutionalism in Latin America: a new Latin American Ius Commune. Disponível em: https://ssrn.com/abstract=2847579. Acesso em: 12 fev. 2021.

GARGARELLA, Roberto. La sala de máquinas de la Constitución: dos siglos de constitucionalismo em América Latina (1810-2010). Buenos Aires: Katz, 2014.

GODOY, Miguel Gualano de. Devolver a constituição ao povo: crítica à supremacia judicial e diálogos institucionais. Belo Horizonte: Fórum, 2017.

GÓES, Luciano. O realismo marginal racial brasileiro. Nuestrapraxis: Revista de Investigación Interdisciplinaria y Crítica Jurídica, v. 1, n. 2, p. 38-55, 2018. Disponível em: https://aneicj. files.wordpress.com/2019/06/goes.pdf. Acesso em: 9 fev. 2021.

GUIMARÃES, Lívia Gil. Participação social no STF: repensando o papel das audiências públicas. Revista Direito \& Práxis, Rio de Janeiro, v. 11, n. 1, p. 236-271, 2020. Disponível em: https:// www.scielo.br/pdf/rdp/v11n1/2179-8966-rdp-11-01-236.pdf. Acesso em: 15 abr. 2021.

KLARE, Karl E. Legal culture and transformative constitutionalism. South African Journal on Human Rights, v. 14, n. 1, p. 146-188, 1998. Disponível em: https://www.tandfonline.com/doi /10.1080/02587203.1998.11834974. Acesso em: 20 jan. 2021.

MBEMBE, Achille. Necropolítica: biopoder, soberania, estado de exceção, política da morte. São Paulo: N1, 2018.

MUNANGA, Kabengele. Teoria social e relações raciais no Brasil contemporâneo. Cadernos Penesb: periódico do programa de educação sobre o negro na sociedade brasileira, Niterói, n. 12, p. 169-203, 2010.

PIRES, Victor. Quilombolas vão ao STF exigir ações do governo federal contra a Covid-19. Instituto Socioambiental, 10 set. 2020. Disponível em: https://www.socioambiental.org/ pt-br/noticias-socioambientais/quilombolas-vao-ao-stf-exigir-acoes-do-governo-federalcontra-a-covid-19. Acesso em: 18 fev. 2021.

ROA ROA, Jorge Ernesto. El rol del juez constitucional en el constitucionalismo transformador latinoamericano. MPIL Research Paper Series, n. 2020-11. Disponível em: https://ssrn.com/ abstract $=3571507$. Acesso em: 11 fev. 2021.

ROUX, Theunis. Legitimating transformation: political resource allocation in the South African Constitutional Court. Democratization, v. 10, n. 4, p. 92-111, 2003. Disponível em: https:// 
www.researchgate.net/publication/240521321_Legitimating_transformation_Political_ resource_allocation_in_the_South_African_Constitutional_Court. Acesso em: 12 fev. 2021.

ROUX, Theunis. Transformative constitutionalism and the best interpretation of the South African Constitution: distinction without a difference? Stellenbosch Law Review, v. 2, p. 258-285, 2009. Disponível em: https://pdfs.semanticsholar.org/5eae/ e8eb64bd96f248d8eb39fa61660129576be.pdf?_ga=2.36844192.1693293173.15799016145179901614. Acesso em: 15 fev. 2021.

SANTOS, Natália Neris da Silva. A voz e a palavra do movimento negro na Assembleia Nacional Constituinte (1987/1988): um estudo das demandas por direitos. 2015. 205 f. Dissertação (Mestrado em Direito) - Escola de Direito, Fundação Getúlio Vargas, São Paulo, 2015.

SISTEMA IBGE DE RECUPERAÇÃO AUTOMÁTICA (SIDRA). Pesquisa nacional por amostra de domicílios contínua trimestral: tabela 6403 - população, por cor ou raça. IBGE, 2020. Disponível em: https://sidra.ibge.gov.br/tabela/6403\#resultado. Acesso em: 20 fev. 2021.

WESTRUPP, Cristiane; LIMA, Fernanda da Silva. Racismo, luta antirracista e os movimentos sociais negros: o crime do racismo em debate. Revista Direito Universidade Federal Mato Grosso do Sul, Campo Grande, MS, v. 6, n. 1, p. 69-94, jan./jun. 2020. Disponível em: https:// periodicos.ufms.br/index.php/revdir/article/view/10510/7984. Acesso em: 15 abr. 2021

\section{Jurisprudência citada}

BRASIL. Supremo Tribunal Federal (Tribunal Pleno). Ação Declaratória de Constitucionalidade41/DF. Relator: Min. Roberto Barroso, 8 dejunho de 2017. Disponívelem: https://www.stf.jus.br/portal/inteiroTeor/obterInteiroTeor.asp?idDocumento=13375729. Acesso em: 3 jun. 2021.

BRASIL. Supremo Tribunal Federal (Tribunal Pleno). Ação Direta de Inconstitucionalidade 3.092/SP. Relator: Min. Marco Aurélio, 22 de junho de 2020. Disponível em: https://www.stf.jus. br/portal/inteiroTeor/obterInteiroTeor.asp?idDocumento=753483771. Acesso em: 3 jun. 2021.

BRASIL. Supremo Tribunal Federal (Tribunal Pleno). Ação Direta de Inconstitucionalidade 3.330/DF. Relator: Min. Ayres Britto, 3 de maio de 2012. Disponível em: https://www.stf.jus. br/portal/inteiroTeor/obterInteiroTeor.asp?idDocumento=3530112. Acesso em: 3 jun. 2021.

BRASIL. Supremo Tribunal Federal (Tribunal Pleno). Arguição de Descumprimento de Preceito Fundamental 186/DF. Relator: Min. Ricardo Lewandowski, 26 de abril de 2012. Disponível em: https://www.stf.jus.br/portal/inteiroTeor/obterInteiroTeor. asp?idDocumento=6984693. Acesso em: 3 jun. 2021 .

BRASIL. Supremo Tribunal Federal (Decisão Monocrática). Decisão de Convocação de Audiência Pública na Arguição de Descumprimento de Preceito Fundamental 635/RJ. 
Relator: Min. Edson Fachin, 17 de dezembro de 2020. Disponível em: https://portal.stf.jus. $\mathrm{br} /$ processos/downloadPeca.asp? id=15345318261\&ext=.pdf. Acesso em: 3 jun. 2021.

BRASIL. Supremo Tribunal Federal (Tribunal Pleno). Habeas Corpus 82.424/RS. Relator: Min. Moreira Alves. Redator para o acórdão: Min. Maurício Corrêa, 17 de setembro de 2003. Disponível em: https://stf.jus.br/portal/inteiroTeor/obterInteiroTeor. asp ? numero $=82424 \&$ classe $=$ HC. Acesso em: 3 jun. 2021.

BRASIL. Supremo Tribunal Federal (Segunda Turma). Habeas Corpus 86.452/RS. Relator: Min. Joaquim Barbosa, 7 de fevereiro de 2006. Disponível em: https://stf.jus.br/portal/ inteiroTeor/obterInteiroTeor.asp?numero=86452\&classe=HC. Acesso em: 3 jun. 2021.

BRASIL. Supremo Tribunal Federal (Tribunal Pleno). Inquérito 1.458/RJ. Relator: Min. Marco Aurélio, 15 de outubro de 2003. Disponível em: https://stf.jus.br/portal/inteiroTeor/ obterInteiroTeor.asp? numero=1458\&classe=Inq. Acesso em: 3 jun. 2021.

BRASIL. Supremo Tribunal Federal (Primeira Turma). Inquérito 4.694/DF. Relator: Min. Marco Aurélio, 11 de setembro de 2018. Disponível em: https://www.stf.jus.br/portal/ inteiroTeor/obterInteiroTeor.asp?idDocumento=750302384. Acesso em: 3 jun. 2021 .

BRASIL. Supremo Tribunal Federal (Tribunal Pleno). Medida Cautelar na Arguição de Descumprimento de Preceito Fundamental 347/DF. Relator: Min. Marco Aurélio, 9 de setembro de 2015. Disponível em: https://www.stf.jus.br/portal/inteiroTeor/ obterInteiroTeor.asp?idDocumento=10300665. Acesso em: 3 jun. 2021.

BRASIL. Supremo Tribunal Federal (Tribunal Pleno). Referendo em Tutela Provisória Incidental na Medida Cautelar na Arguição de Descumprimento de Preceito Fundamental 635/RJ. Relator: Min. Edson Fachin, 05 de agosto de 2020. Disponível em: https://www.stf.jus.br/portal/inteiroTeor/obterInteiroTeor.asp?idDocumento $=754312998$. Acesso em: 3 jun. 2021.

BRASIL. Supremo Tribunal Federal (Tribunal Pleno). Referendo na Medida Cautelar na Arguição de Descumprimento de Preceito Fundamental 709/DF. Relator: Min. Roberto Barroso, 5 de agosto de 2020. Disponível em: https://www.stf.jus.br/portal/inteiroTeor/ obterInteiroTeor.asp?idDocumento=754033962. Acesso em: 3 jun. 2021.

BRASIL. Supremo Tribunal Federal (Tribunal Pleno). Referendo na Medida Cautelar na Arguição de Descumprimento de Preceito Fundamental 738/DF. Relator: Min. Ricardo Lewandowski, 26 de outubro de 2020. Disponível em: https://www.stf.jus.br/portal/ inteiroTeor/obterInteiroTeor.asp?idDocumento=754239593. Acesso em: 3 jun. 2021.

BRASIL. Supremo Tribunal Federal (Decisão Monocrática). Tutela Provisória Incidental na Medida Cautelar na Arguição de Descumprimento de Preceito Fundamental 635/ RJ. Relator: Min. Edson Fachin, 05 de junho de 2020. Disponível em: https://portal.stf. jus.br/processos/downloadPeca.asp? id=15343352680\&ext=.pdf. Acesso em: 3 jun. 2021. 


\section{Legislação citada}

BRASIL. [Constituição (1988)]. Constituição da República Federativa do Brasil de 1988. Brasília: Presidência da República, [2021]. Disponível em: https://www.planalto.gov.br/ ccivil_03/constituicao/constituicao.htm. Acesso em: 20 fev. 2021.

BRASIL. Lei no 7.716, de 5 de janeiro de 1989. Define os crimes resultantes de preconceito de raça ou de cor. Brasília: Presidência da República, [2012]. Disponível em: https://www. planalto.gov.br/ccivil_03/leis/17716.htm. Acesso em: 20 fev. 2021.

BRASIL. Lei no 10.639, de 9 de janeiro de 2003. Altera a Lei no 9.394, de 20 de dezembro de 1996, que estabelece as diretrizes e bases da educação nacional, para incluir no currículo oficial da Rede de Ensino a obrigatoriedade da temática "História e Cultura Afro-Brasileira", e dá outras providências. Brasília: Presidência da República, [2003] Disponível em: https:// www.planalto.gov.br/ccivil_03/leis/2003/110.639.htm. Acesso em: 20 fev. 2021.

BRASIL. Lei no 12.990, de 9 de junho de 2014. Reserva aos negros 20\% (vinte por cento) das vagas oferecidas nos concursos públicos para provimento de cargos efetivos e empregos públicos no âmbito da administração pública federal, das autarquias, das fundações públicas, das empresas públicas e das sociedades de economia mista controladas pela União. Brasília: Presidência da República, [2014]. Disponível em: https://www.planalto.gov.br/ccivil_03/_ ato2011-2014/2014/lei/112990.htm. Acesso em: 20 fev. 2021. 